$12-1-2008$

\title{
Time, Judgment, and Competitive Spirituality: A Reading of the Development of the Doctrine of Purgatory
}

John E. Thiel

Fairfield University, jethiel@fairfield.edu

Follow this and additional works at: https://digitalcommons.fairfield.edu/religiousstudies-facultypubs

\section{Peer Reviewed}

\section{Repository Citation}

Thiel, John E., "Time, Judgment, and Competitive Spirituality: A Reading of the Development of the Doctrine of Purgatory" (2008). Religious Studies Faculty Publications. 45.

https://digitalcommons.fairfield.edu/religiousstudies-facultypubs/45

\section{Published Citation}

Thiel, John E. "Time, Judgment, and Competitive Spirituality: A Reading of the Development of the Doctrine of Purgatory." Theological Studies 69.4 (2008): 741-785.

This item has been accepted for inclusion in DigitalCommons@Fairfield by an authorized administrator of DigitalCommons@Fairfield. It is brought to you by DigitalCommons@Fairfield with permission from the rightsholder(s) and is protected by copyright and/or related rights. You are free to use this item in any way that is permitted by the copyright and related rights legislation that applies to your use. For other uses, you need to obtain permission from the rights-holder(s) directly, unless additional rights are indicated by a Creative Commons license in the record and/or on the work itself. For more information, please contact digitalcommons@fairfield.edu. 


\title{
TIME, JUDGMENT, AND COMPETITIVE SPIRITUALITY: A READING OF THE DEVELOPMENT OF THE DOCTRINE OF PURGATORY
}

\author{
JOHN E. THIEL
}

\begin{abstract}
Why has purgatory virtually disappeared from Catholic belief and practice since Vatican II? A competitive spirituality, gravitating around the religious vocation of ascetics from the late Middle Ages, enabled the doctrine by extending the temporal horizon within which God's favorable judgment could be secured, first, in the lifelong practice of ascetics in their spiritual competition with martyrs, and then into a supernatural time required for laypersons and ascetics who could not meet the standard set by saintly ascetics. The loss of this competitive spirituality after Vatican II led to the loss of belief in purgatory and devotional practice surrounding it.
\end{abstract}

$\mathrm{F}$ OR MANY CATHOLICS IN THE POSTCONCILIAR CHURCH purgatory has fallen off the eschatological map. It is difficult to know exactly why this has occurred. One reasonable explanation might run along the following lines. The theological and pastoral reception of the Second Vatican Council highlighted the power of God's grace in bringing believers to salvation, and that emphasis undermined the detailed accounting of personal virtue and $\sin$ in the Tridentine merit system. This accent on the graciousness of divine love brought about a seismic shift in Catholic belief and practice. Conservatives in the Church would continue the explanation by concluding that the postconciliar theology of God's infinite mercy and compassion tragically eclipsed the preconciliar sense of the power of personal sin. This diminishment of the sense of sin has had repercussions for a host of other mutually related beliefs and practices that explain the contemporary indifference toward purgatory. The diminishment of the sense of personal sin has been attended by a transformed understanding of the saintly life as an epiphany of virtue, though not virtue achieved through difficult struggle with sin. The diminishment of the sense of personal sin has led to the

John E. THIEL received his Ph.D. from McMaster University, Hamilton, Ontario, and is now professor of religious studies and director of the honors program at Fairfield University, Fairfield, Connecticut. Specializing in systematic and fundamental theology, he has recently published God, Evil, and Innocent Suffering (Crossroad, 2002) and Senses of Tradition: Continuity and Development in Catholic Faith (Oxford University, 2000). In progress is a monograph on eschatology. 
virtual disappearance of the sacrament of penance in popular Catholic practice, a change in religious behavior that reflects the loss of a belief in the rigor of divine judgment. And since purgatory is about judgment, it is hardly surprising that the doctrine of purgatory has largely disappeared from Catholic belief and practice.

This article, though, offers a somewhat different explanation for the disappearance of purgatory in contemporary Catholic belief and practice, and one that does not reduce its disappearance to the tragic. This explanation will depend on an argument that $I$ offer in these pages for the development of the doctrine of purgatory. My purpose is to reflect on the development of the doctrine of purgatory in order to appreciate the workings of judgment in the Catholic tradition. I will not attempt a theological retrieval of the doctrine of purgatory. I am entirely open to the possibility that there is value in such a retrieval, but that is not my project here. Instead, the doctrine of purgatory will serve as a resource for elucidating the anxieties and hopes that attend the Catholic belief in divine judgment. I readily concede at the outset that my argument will not please professional historians. It is sweeping in its historical scope, speculative in its judgments, and leads, in the end, to constructive conclusions. The story I tell will have historical contours, and its main characters will be Catholic Christians who have lived their lives in the tradition's two, broad vocations-ascetics and laypersons. I begin the story by considering the recent revival of scholarly interest in purgatory that has been prompted by the work of Jacques Le Goff.

\section{EXPLAINING PURGATORY}

No study has had a greater influence on our understanding of the development of purgatory as a Catholic belief than Jacques Le Goff's The Birth of Purgatory (1981). ${ }^{1}$ Le Goff argues that purgatory came into full bloom as a Catholic belief and doctrine rather late, in the twelfth century. Established at that time as a "third place" in the afterlife along with heaven and hell, purgatory became "an intermediary other world in which some of the dead were subjected to a trial that could be shortened by the prayers, by the spiritual aid of the living." 2 Hints of such beliefs abound in the earlier tradition, whether in affirmations of otherworldly purgation or in ancient accounts of near-death experiences in which the

${ }^{1}$ Jacques Le Goff, The Birth of Purgatory, trans. Arthur Goldhammer (Chicago: University of Chicago, 1984). For critical assessments of this work see Graham Robert Edwards, "Purgatory: 'Birth' or Evolution?" Journal of Ecclesiastical History 36 (1985) 634-46; and Brian Patrick McGuire, "Purgatory, the Communion of the Saints, and Medieval Change," Viator 20 (1989) 61-84.

${ }^{2}$ Le Goff, Birth of Purgatory 4. 
believer is conducted on a journey through hell so that, chastened by the terrible sight, he or she can regard earthly life as an opportunity for repentance. But, for Le Goff, nothing in the earlier tradition compares with the elaboration of purgatory in the religious imagination of twelfth-century Europe. Purgatory not only achieved specificity as a "third place" but also took shape in a detailed theology of retribution, sacrifice, penalties, pardons, and spiritual exchange among the dead and the living. Purgatory has continued to capture the Catholic imagination until very recently, achieving doctrinal definition in the late medieval period and enjoying "a more ample existence... in the leading Catholic styles of the fifteenth to the nineteenth centuries." Since Le Goff concedes that "Purgatory is rooted in the theology of the post-Tridentine catechism," ${ }^{3}$ he might have carried this period of flourishing to the eve of Vatican II, in the aftermath of which belief in purgatory has all but disappeared.

Central to Le Goff's thesis is his attribution of the twelfth-century birth of purgatory to social-historical causes. Cities began to rise in Europe at this time, creating a third, social group of merchants alongside the traditional two of empowered nobles and clergy, on the one hand, and the powerless peasantry, on the other. The binary eschatological destinies of heaven and hell were now imaginatively supplemented by a third, temporary destination that projected the new intermediate social group into the afterlife, along with all the social ambiguity of future success and failure that typified the life of the new merchant group. In Le Goff's words: "between the great (lay and ecclesiastic) and the small (rural and urban workers) an intermediate category had been born, namely, the 'bourgeois,' who formed a group so diverse that I prefer not to speak of it as a class." 4 Le Goff does not reduce the birth of purgatory to the single cause of social stratification in the urban development of the high Middle Ages. He insists that it would be absurd to argue that "the bourgeoisie created Purgatory, or that Purgatory in one way or another derived from the bourgeoisie, assuming a bourgeoisie even existed at the time." Rather, he makes the more modest or, as he calls it, "hypothetical" interpretation that medieval men and women could only think and imagine in terms of their social and economic structures, and that dramatic changes in these structures could not help but be reflected in their thinking about life after death. It is difficult to disagree with Le Goff on this point, at least as a partial explanation of the development of this doctrine.

As an Annales historian, Le Goff is strongly committed to social historiography. And yet, in spite of this commitment, he troubles over the

\footnotetext{
${ }^{3}$ Ibid. 357.

5 Ibid.

${ }^{4}$ Ibid. 226.
} 
adequacy of this explanatory approach in the book's concluding pages. $\mathrm{He}$ admits that his argument has made purgatory the "key component" in explaining the medieval system of ideas. Purgatory holds this central place in his argument since, in his judgment, it captures something new in the developing structure of late medieval society. Early medieval thinking moved in a binary framework that reflected the feudal social division of rich and poor, empowered and disempowered. The twelfth century witnessed a shift to a trinary mode of thinking that mirrored the appearance of the new merchant class, and that valorized purgatory in an otherworldly landscape that previously had highlighted the eternal binaries of heaven and hell. The newness of an elaborate theology of purgatory in the later Middle Ages represented the newness of the nascent urban culture and accounts for the centrality of purgatory in Le Goff's social-historical explanation. But, Le Goff wonders, "isn't it possible that the real energizing and organizing force of the system lay not in Purgatory but in Heaven?" Even though the sources portray purgatory as a place of suffering, perhaps "Purgatory's center of gravity may have shifted so far toward Paradise as to make the desire for Heaven the energizing force of Christian doctrine." Wondering next about the adequacy of his account from the opposite direction, Le Goff questions whether belief in purgatory developed as it did in order for "the Church to preserve the belief in Hell everlasting" by "introducing a temporary Purgatory mainly to throw the inextinguishable fires of Hell into sharp relief."7

These are challenging questions to raise at the end of a rather ardent argument, and they show Le Goff's admirable capacity for self-criticism. Le Goff does not answer these questions, nor does he pose them only to dismiss them and reclaim the explanatory power of his argument. His book ends with the questions left standing, testimonies to what he describes as his nagging anxiety about the adequacy of his argument. ${ }^{8}$ And this is a productive anxiety indeed. Had Le Goff pursued these questions and argued in heavenly or hellish directions, one expects that he would have constructed theses that resembled the one advanced in the book he did write, his scholarly mindset and method unswervingly committed to social historiography. But his questions also delimit the boundaries of socialhistorical explanation by highlighting the importance of religious emotions in a system of doctrine, and so in any attempt at historical explanation. Perhaps, Le Goff considers, the yearning for heaven or the fear of hell are more central to Christian concern about the otherworld than purgatory itself, and perhaps purgatory is but a derivative way of speaking about the yearning for heaven or the fear of hell, or possibly even both!

6 Ibid. 358.

${ }^{7}$ Ibid. 359.

${ }^{8}$ Ibid. 358. 
Religious emotions like yearning and fear, of course, always unfold in determinate social-historical circumstances that mold them in complex ways, and so a more complete study of these emotions would need to explain the particular cultural setting that produced them. And yet, this same observation applies, mutatis mutandis, to a predominantly socialhistorical explanation. Even though religious beliefs and practices can be explained as a function of social-historical causes, they, in turn, can produce powerful religious emotions whose consistent meaning contributes to the integrity of an identifiable religious tradition. As much as these meaningful emotions are particularized by time, place, and circumstance, they may shape the determinate historical conditions within which they appear and to an extent that obliges the interpreter to consider the causal consequences of their consistent meaning over time.

I now consider this point with respect to purgatory. "Purgatory-like" beliefs have flourished throughout Christian history, especially in Latin Christianity, in what eventually came to be identified as the Roman Catholic tradition, and even in the popular culture where these beliefs have had currency. Origen's third-century belief in earthly life as successive reincarnations in which the soul is gradually educated to conformity with the divine will; Augustine's fifth-century mention of a supernatural, purifying fire in the City of God; Gregory the Great's seventh-century stories of near-death experiences in which believers return to life after experiencing a vision of hell so that their sins could be purged by renewed moral effort in this life; Catherine of Genoa's classical 16th-century account of the late medieval theology of purgatory as an otherworldly third place; Le Goff's observation that this classical theme saw variations in a "Counter Reformation Purgatory, ... a baroque Purgatory, a romantic Purgatory, and a Sulpician Purgatory"; ${ }^{9}$ and the widespread practice of purgatorial intercession in Tridentine Catholicism in general to the eve of Vatican II all testify to the consistent appearance of purgatory-like beliefs in the tradition. If one assumes that this consistent appearance expresses at least the possibility of consistent and meaningful religious emotions, then the interpreter cannot ignore that possibility in proposing historical explanations. Any effort to explain why these purgatorial beliefs have persisted throughout the tradition is susceptible to the same kind of reductionism about which

${ }^{9}$ Ibid. 357. For a comprehensive account of purgatorial belief in historical perspective, see Albert Michel, "Purgatoire," in Dictionnaire de théologie catholique: Contenant l'exposé des doctrines de la théologie catholique, leurs preuves et leur histoire, ed. A. Vacant and E. Mangenot, vol. 13/1 (Paris: Letouzey, 1936) 11631326. 
Le Goff worried in his approach. Moreover, social-historical criticism rightly has made us wary of essentialist tendencies in homologous explanation. Nevertheless, the abiding expression of the same kinds of religious hopes and fears begs for explanation at the level of the historically similar, just as much as beliefs marked by time and place beg for explanation at the level of the historically different.

In the pages that follow, I explore how the consistent appearance of the religious emotion of anxiety, fueled by competition for heaven between and among martyrs, ascetics, and laypersons, does much to account for the development of the doctrine of purgatory in the Catholic tradition. I do not consider this perspective on the development of the doctrine to be exhaustive. I offer the argument presented here only as another layer of explanation that, if credible, may complement the many recent scholarly accounts of the doctrine of purgatory.

\section{ESCHATOLOGICAL ANXIETY}

Purgatory is not explicitly mentioned among the four "last things"death, judgment, heaven, and hell. But purgatory is entirely about the judgment that believers expect to face in the afterlife as a consequence of their lives here and now. The first shades of belief in what later developed into the medieval doctrine of purgatory appear as early as Augustine's fifth-century speculations about judgment in the City of God. In Book 21, the North African bishop opines that "not all men who endure temporal pains after death come into those eternal punishments, which are to come after that judgment. Some, in fact, will receive forgiveness in the world to come for what is not forgiven in this ... so that they may not be punished with the eternal chastisement of the world to come."10 This early conception links purgation to the judgment that God has made on those who suffer otherworldly pain. But judgment, in Christian belief, is not confined to supernatural purgation. Judgment has been a matter of concern from the tradition's earliest days, no doubt because it assesses the believer's consummate relationship to God, and so the believer's eternal destiny.

The early Christian conception of judgment was bound up with the zealous belief in Jesus' imminent return to the world as eschatological judge. Christian hope in this saving event drew on the religious energies of the Jewish apocalyptic tradition, which may have inspired the preaching of

${ }^{10}$ Augustine, Concerning the City of God against the Pagans, trans. Henry Scowcroft Bettenson, intro. John O'Meara (New York: Penguin, 1984) 990-91 (Book 21.13). In Book 21.26, Augustine speaks of a purifying fire as the cause of the otherworldly pain of purgation, an idea he mentions in several of his works. See Joseph Ntedika, L'évolution de la doctrine du purgatoire chez Saint Augustin (Paris: Études Augustiniennes, 1966). 
Jesus himself. One possible textual candidate for this influence is the Jewish Book of Daniel, whose vision of the Son of Man "coming with the clouds of heaven" (Dan 7:13) captured first-century Christian imagination on the manner of Jesus' return. Daniel sees the end-time as God's judgment on his people that will "bring some to everlasting life, and some to everlasting contempt" (Dan 12:2), a judgment of division that would later appear prominently in the Gospel of Matthew. The theology of the $Q$ material, written or orally transmitted sayings of Jesus on the responsibility of discipleship, highlights the judgment that early Christians expected to accompany the coming of God's kingdom. Jesus' exhortations to virtue of the highest order in the $\mathrm{Q}$ sayings make impending judgment a horizon before which Christian commitment finally will be proved. Even though Matthew and Luke (75-85 CE) wove the $\mathrm{Q}$ material into larger gospel frameworks that tempered its apocalyptic fervor, they yet followed $\mathrm{Q}$ in making the judging expectations of Jesus the criterion of virtuous action for their Christian communities. These late first-century churches could aspire to ethical heights that required even the love of one's enemies (Mt 5:44; Lk 6:27), believing as they did that such virtue was an obligation for those who lived in an already immanent kingdom of God.

The early church defined the criterion of judgment not only by the teaching of Jesus but also by the martyrs' extraordinary example of Christic imitation. The Book of Revelation, written around $100 \mathrm{CE}$, provides early testimony of the martyrs' privileged place in the apocalyptic drama. As the events of the end-time unfold, John sees the "souls of those beheaded for their testimony to Jesus and for the Word of God" standing before those enthroned and "given authority to judge." The martyrs are vindicated for their sacrifice by sharing in the "first resurrection," by which they "came to life and reigned with Christ a thousand years" (Rev 20:4, 5). Their immediate judgment and salvation distinguishes them from other believers. As "blessed and holy" and as "priests of God and of Christ," the martyrs provided a measure in the late first-century church of the most authentic discipleship to which believers might aspire in their own appearance before the Judge who would soon vanquish the powers of the world.

It is interesting to speculate about what sort of emotions were stirred in the earliest Christians by this expectation of judgment upon the return of Christ. Paul, writing in the middle years of the first century, chastises members of the Christian community in Rome for judging each other when it is only God's place to judge. "For we will all stand before the judgment seat of God," he writes, where "each of us will be accountable to God" (Rom 14:10,12). And yet Paul's strong doctrine of grace seems to expect the parousia as an irresistible wave of grace that will bring those baptized in Christ to heavenly bliss in spite of their utter sinfulness. For Paul, human sinfulness is as inescapable as the death that he believes sin causes (Rom 
5:12). Before the Jewish Law, all are judged unfavorably since no deed that issues from human nature can elude self-interest and vanity. "I can will what is right," Paul concedes, "but I cannot do it. For I do not do the good I want, but the evil I do not want is what I do" (Rom 7:18-19). This Pauline style of faith, then, takes for granted that God's judgment on every human life, and, even more, on every human deed requires the verdict of condemnation (Rom 5:16). All human beings deserve a death that is final and from which there is no rescue. In Paul's view, God's love and mercy are not beholden to this just verdict but instead break it to pieces. Out of the rubble of sin, death, and condemnation, God brings the surprising and undeserved gift of eternal life in the resurrection of Christ from the dead, which, Paul believes, brings in turn the gift of resurrected life to believers (1 Cor 15:12-19). Since Paul's audience comprises newly baptized Christians who have experienced this gift of eternal life, his letters testify consistently to the victory of grace, even to the point that they make no mention of final condemnation or hell. The Pauline style of faith understands the resurrection of Christ to have annulled God's righteous verdict of condemnation on human sin, and so the emotion that characterizes its belief before the coming judgment is gratitude. ${ }^{11}$

The style of faith that we find in the Synoptic Gospels of Mark, Matthew, and Luke is quite different, as is the range of emotions it likely evoked in believers. Here, the grace of God that breaks into the world in the life, death, and resurrection of Jesus expects the proof of discipleship in deeds that imitate the Savior's life and by which the believer will be judged. Judgment in this style of faith does not move in the trajectory of Pauline thought. God's judgment presupposes human responsibility not only for sin but also for virtue. Moreover, judgment in this style of faith highlights the believer's active decision before the alternatives of moral achievement or moral failure, and ultimately before the eschatological destinies of heavenly glory or infernal condemnation. Even though we find these beliefs about judgment in all three Synoptic Gospels, they are so pointedly expressed in Matthew that I will name this style of faith "Matthean." In words that echo the eschatological sensibilities of $Q$, Matthew conveys this sense of judgment sharply in the reproach Jesus brings on the cities that fail to repent before his "deeds of power": "Woe to you, Chorazin! Woe to you, Bethsaida! For if the deeds of power done in you had been done in Tyre and Sidon, they would have repented long ago in sackcloth and ashes. But I tell you, on the day of judgment it will be more tolerable for Tyre and Sidon than for you. And you, Capernaum, will you be exalted to heaven?

${ }^{11}$ Paul, of course, assumes that undeserved grace brings the believer to ethical responsibility that flourishes in virtuous deeds. See, for example, 1 Cor 9:24-27; 2 Cor 5:9-10; Gal 6:7-10. 
No, you will be brought down to Hades" (Mt 11:21-23). For Matthew, this judgment of division-in Jesus' words-cannot be separated from the return of the Son of Man: "For as the lightening comes from the east and flashes as far as the west, so will be the coming of the Son of Man.... Then two will be in the field; one will be taken and one will be left. Two women will be grinding meal together; one will be taken and one will be left. Keep awake therefore, for you do not know on what day your Lord is coming"" (Mt 24:27, 40-42).

Matthew completes this vision of eschatological division in a passage that exerted a profound influence on Christian belief in the Last Judgment. Continuing to explain the end-times to his disciples, Matthew's Jesus says: "When the Son of Man comes in his glory, and all the angels with him, then he will sit on the throne of his glory. All the nations will be gathered before him, and he will separate people one from another as a shepherd separates the sheep from the goats, and he will put the sheep at his right hand and the goats at the left" (Mt 25:31-33). This judgment is rendered on the fruits of discipleship. Those who have earned the crown of heaven fed the hungry, gave drink to the thirsty, welcomed the stranger, clothed the naked, cared for the sick, and visited the imprisoned (Mt 25:35-36). Jesus condemns those who did not accomplish these deeds to "the eternal fire prepared for the devil and his angels" (Mt 25:41). This same logic of division appears in Mark and Luke to the extent that Jesus calls believers to a discipleship of deeds measured by the sacrifice of the cross, a standard that Jesus had defined in his own saving death and that each martyr profoundly imitated in the act of becoming a saint.

The Matthean style of faith, no doubt, was satisfying to believers since it became the majority belief of the Christian tradition. But the satisfaction it brought also occasioned a certain kind of concern that I call "eschatological anxiety." By this term I mean emotional consternation about one's eternal destiny, which, in a Christian context, amounts to worry about the final integrity of one's life, about its ultimate meaningfulness or meaninglessness, about its consummate happiness or desolation. This anxiety emerges in the prospect of a judgment before God in which one's deeds and misdeeds truly matter. As already noted, the Pauline style of faith assumes that all human deeds are wanting. Sin seeps so deeply into every natural act that there is no natural virtue. But the Matthean style of faith presupposes the believer's active responsibility before real alternatives in eternal destiny. Believers in this style of faith understand their acts of discipleship to be energized by the grace of Christ. Perseverance on the gospel's difficult road cannot be credited to human powers alone. And yet, human initiative makes a distinct contribution to the journey of salvation, and without it there is no righteousness before the divine judge. That such action is measured by the high standards provided by the ethical commands of Jesus in 
Scripture, his passion and death, and the martyr's heroic example of imitation-and all before the prospect of Christ's imminent return as judgecertainly stirred anxiety among early believers whose ethical performance fell short of their martyred peers, an anxious group of nearly all. ${ }^{12}$

Christian faith in the Late Antique world developed along the lines of this Matthean style of faith, proliferating as a religious perspective that Peter Brown has called the "peccatization" of the world. ${ }^{13}$ As the apocalyptic expectations of the first century receded, and, even more, as the age of persecution ended and Christianity entered the ordinary time of late Roman Antiquity, judgment took shape in the believer's sense of sin and in the need of forgiveness before God's righteousness. By the fifth century, Brown argues, Christians came to be especially concerned about the "peccata levia, the day-to-day sins" ${ }^{14}$ of those who were not blatantly saints and not blatantly the damned, that is, the Christian masses who were

${ }^{12}$ All the talk here of Paul and Matthew as representative of two styles of early Christian faith raises questions about how the Gospel of John compares. There are, of course, many styles of first-century Christian faith. The literary evidence suggests that there are at least as many as there are texts. The Gospel of John is one important example that had a prominent influence on the later tradition, especially through its Christology of preexistence. John, however, was far less influential on the later tradition than Matthew with respect to the issues of discipleship and judgment. Like Paul, John highlights the power of God's grace in a way that draws his attention away from the theme of virtuous responsibility. On this point see Alan E. Bernstein, The Formation of Hell: Death and Retribution in the Ancient and Early Christian Worlds (Ithaca, N.Y.: Cornell University, 1993) 224-27. John's theology of grace thus tended to obviate a rigorous ethic of discipleship, the likes of which we find in the Gospel of Matthew. Much in the manner that the Christology of the Synoptic Gospels was absorbed into John's high Christology of preexistence in the tradition's later, uncritical readings of the New Testament, John was absorbed into the Matthean theology of discipleship and divine judgment. I have distinguished only two styles of Christian faith-Pauline and Matthean-on the basis of their history of effects on the Christian tradition.

${ }^{13}$ Peter Brown, "The Decline of the Empire of God: Amnesty, Penance, and the Afterlife from Late Antiquity to the Middle Ages," in Last Things: Death and the Apocalypse in the Middle Ages, ed. Carol Walker Bynum and Paul Freedman (Philadelphia: University of Pennsylvania, 2000) 58.

${ }^{14}$ Ibid. 43. Unlike Le Goff, Andreas Merkt is willing to consider the origins of purgatory in a host of Late Antique Christian beliefs, among them Brown's notion of the peccata levia. Merkt finds this idea first in Cyprian's willingness to conceive the church not simply as a community of the perfect but as a community that embraced the repentant sinner. This ecclesiology defined a category of Christians who were neither certainly saved nor certainly lost, and which Augustine came to call the "not very good and not very bad." Merkt argues that this third category of believers, perched in the salvational hierarchy between the martyrs and the damned, provided a seedbed for the growth of purgatory. See Andreas Merkt, Das Fegfeuer: Entstehung und Funktion einer Idee (Darmstadt: Wissenschaftliche Buchgesellschaft, 2005) 65-68. 
increasingly visible in the emerging feudal world. All the baptized, whether monastic or lay, imagined the Christian life as an extended purification of the soul in preparation for its eschatological encounter with God. Even though grace was assumed to be at work in the believer's salvation, "the center of gravity of the imaginative structure associated with the notion of purification rested heavily on the individual and on his or her ability to take on full responsibility for his or her own healing." 15 The late Roman legal system provided a cultural context in which the Matthean style of faith could more exactly take account of every sin and measure the virtuous recompense owed God, a calculation that mirrored the secular amnesty that violators of imperial law sought from the emperor. Brown points out that this understanding of the Christian life as an accounting for sin valorized personal death as the moment of eschatological encounter with God. "Neither in late antiquity nor in the early middle ages," he avers, "should we underestimate the silent pressure exercised on all Christians by the inscrutable anomaly of death.... In the Christian imagination, the moment of death was an exact reflection, in miniature, of the terror of the Last Judgment."16

It is not surprising that personal death would gain prominence as the moment of eschatological encounter with God. This shift reflected the cultural assimilation of Christianity into Mediterranean society, its embrace of the day-to-day life of the civic realm where, as Brown points out, the believer struggled constantly to make amends for his or her day-to-day sins. Christian life became quotidian for a host of reasons-the end of persecution, the rise of the institutional church, and the alliance of political and ecclesiastical authorities. But we should not overlook the fact that Christian life also became quotidian because the imminent apocalypse expected by the earliest Christians did not occur. In response, Christians

${ }^{15}$ Brown, "Decline of the Empire of God" 47.

${ }^{16}$ Ibid. 44, 45. Here Brown is supported by the work of Éric Rebillard, who acknowledges that the fear of death and judgment was absent in writings from the earliest Christian centuries. Yet, "au tournant des IVe et Ve siècles, la prédication chrétienne cesse peu à peu d'ignorer, ou de sublimer, les craintes de l'homme face à la mort" (Éric Rebillard, In hora mortis: Évolution de la pastorale chrétienne de la mort aux IVe et Ve siècles dans l'occident latin [Rome: École française de Rome, 1994] 229). Brown sees the moment of death in early Christian belief as a reflection of the Last Judgment. On this point he seems to disagree with Philippe Ariès, who argues that the interval between personal death and the Last Judgment in early Christian belief diminished the importance of the former and valorized the latter. The moment of death, he claims, gathered importance as the scene of judgment only with the rise of a sense of individuality in the late Middle Ages and in the early modern period. See Philippe Ariès, The Hour of Our Death, trans. Helen Weaver (New York: Knopf, 1981) 99-110. Rebillard's important study cited above suggests that Ariès' position requires qualification, if not complete revision. 
retheologized their religious worldview, particularly with respect to the time of judgment. The return of Christ was relegated to a more distant future and invested with the same communal proportions of judgment that first-century Christians had expected soon. This Last Judgment was distinguished from the particular judgment that each believer would face at the time of death as a disembodied soul, a judgment in which the body would share when it was miraculously resurrected and united with the soul on the last day. Personal death replaced the first-century expectation of the apocalypse as the catalyst of eschatological anxiety. Most importantly, the belief in a particular judgment immediately after death quotidianized judgment by enveloping it in the ordinariness of death. As much as the hour of one's own death became religiously extraordinary, "fearful, or simply aweinspiring"17 as the moment of appearance before the divine judge, the ordinariness of death as a human event, witnessed often in the deaths of others, wove judgment into the daily circumstances of life. To the degree that the moment of death was invested with the believer's portfolio of discipleship, judgment made its way back in time into the believer's every sinful and virtuous deed.

Time thus became saturated with judgment as the concern for eternal destiny was extended not only forward, so to speak, from a particular to a reiterated Last Judgment, but also backward into every moment in the believer's life. Unfolding ordinarily in a de-apocalypticized temporality, judgment became an ongoing event in a protracted period of time in which every word and deed entered into the balance of divine justice. As I will show, this new Christian sensibility on time and judgment provided a setting for the development of the doctrine of purgatory in the late Middle Ages.

\section{COPING WITH THE MARTYRS}

The cult of the saints in the Late Antique world is usually explained as a religious practice shaped by the culture of patronage that flourished in Mediterranean society. ${ }^{18}$ The veneration that believers accorded the saints mirrored the bonds of the patron-client relationship, its ties of power and need and its exchange of favors now transferred into the currency of the supernatural and the believer's desire for resurrected life. As a coda to this customary explanation one might also consider how the rise of the cult of

${ }^{17}$ Brown, "Decline of the Empire of God" 44.

${ }^{18}$ Peter Brown, The Cult of the Saints: Its Rise and Function in Latin Christianity (Chicago: University of Chicago, 1981). From the critical perspective of systematic theology, see Elizabeth A. Johnson, Friends of God and Prophets: A Feminist Theological Reading of the Communion of the Saints (New York: Continuum, 1998) 86-92. 
the saints contributed to the domestication of judgment and constituted an interesting site for the negotiation of eschatological anxiety in the early church.

The martyrs continued to provide the standard for Christian virtue throughout the age of persecution, their faithful deaths defining the earliest Christian understanding of the saint. The delay of the parousia, however, led Christians to redefine their conception of judgment and the normativity of saintly imitation. As noted above, the fact that Christ had not returned required the delay of the eschaton into a more distant future. The church relinquished the Book of Revelation's idea of a "first resurrection" of the saints into a chiliastic reign of Christ for 1,000 years, a loss that strengthened the belief in heavenly life after death that appeared in the tradition as early as Paul's letters. A changed notion of the "first resurrection" of the martyrs, though, continued to resonate in the practice of burial ad sanctos. Judging the martyr's physical remains to be sacred, Christians of the early centuries began the practice of regarding their burial places as holy ground, sanctified by the martyr's charismatic presence. The shrine became the destination of pilgrimage, a place to petition the saint for favors that kept deathliness at bay, and also a burial ground for the community's beloved dead. Since the martyr had already passed through judgment and gained divine favor, believers buried their dead in proximity to the saint in the hope that the ordinary faithful would share in the martyr's "first resurrection," 19 now conceived as the privilege the martyr would enjoy in being raised to physical wholeness first of all on the last day. The practice of making the shrines into cemeteries assured the physical closeness of the dead to the saint on the Day of Judgment, an intimacy that, through the power of grace and ample hope, would allow the ordinary believer to participate in the martyr's most favorable judgment.

We might think of this practice, centered in the authority of the martyr's judgment, as a further domestication of eschatology. The practice of burial ad sanctos conceded the delay that Christians had come to expect in the approach of the end-time, nearness to the relics serving as a substitute for what first-century Christians believed to be the nearness of a parousia brought by Christ himself. Christians continued this domestication of eschatology by depositing the relics of the saints into the newly built churches of the fourth and fifth centuries. The relative permanence of the new structures, which reflected an ecclesiology of accommodation to the new era, testified to the distance of the eschaton and to the routinization of the sacred in ordinary time. And as the life of the church was extended into a future that led all the way to the distant eschaton, a premium began to be

${ }^{19}$ Brown, Cult of the Saints 35. 
placed on the Christian life as a more limited horizon of years within which believers struggled to act virtuously in order to make recompense for the failure of sin. Within this more compact and personalized eschatology, the believer's death now became the focal point of judgment, a death packed with all the moments of life that fell under the divine scrutiny and for which the believer was held accountable.

Christian life thus became a duration for the exercise of virtue and the avoidance of sin, a limited time charged with eternal consequences. The cult of the saints was an acknowledgment on the part of the faithful that a few Christians-indeed very few-had used their time extraordinarily well. Believers who came in need to the saints knew that they, the ordinary, were among the many whose sin outweighed their virtuous deeds. The difference between the saint, as one of the few, and the sinner, as one of the many, animated the cult. The martyr's virtuous difference as an extraordinary imitator of the Savior availed the power of eternal life to believers. The difference of the martyr's favorable judgment, accessible to the believer through the martyr's intercession, was a remarkable comfort to the needy faithful who could share in the saint's exceptional difference. But the martyr's difference also stood as a threatening measure of what a believer's life could be. The martyr's death was the consummate act of discipleship since it mirrored Jesus' death on the cross, a standard of virtue that few Christians could, or were willing to, match during the persecution. After the persecution ended in $313 \mathrm{CE}$, the martyr's achievement was placed beyond the possible circumstances of discipleship, securing the authority of the martyr's judgment throughout the tradition. This made the martyr as much a source of eschatological anxiety as a source of eschatological comfort. The martyr's favorable judgment by God was one in which believers could participate through the martyr's cult. But it was also a judgment on the lives of believers that stirred fears about their own judgment.

It would be interesting to consider the rise of Christian asceticism from the turn of the fourth century as a way of negotiating the eschatological anxiety incited by the martyr's judgment. At one level, the notion of the ascetic as holy person was a response to the acculturation of Christianity. The martyr's sacrifice exhausted the early notion of the saint. As the age of persecution ended and the Roman authorities stopped making martyrs, Christians sought an alternative understanding of saintly imitation and found it in the nascent ascetical movement. Ascetical men and women imitated Jesus by willing the sufferings of his passion into their bodies and, by doing so, believed that they shared in his saving atonement in an extraordinary way. Unlike the martyrs, though, the ascetics carried their imitation to a point far short of death. Since the society in which they lived was not hostile to their religious endeavors, martyrdom was not an option. Indeed, as Christian belief provided a matrix of meaning for medieval 
society, ascetics were celebrated as holy persons from whom the ranks of the new saints were drawn, the most accomplished ascetics earning the crown of exceptional holiness. But as much as ascetics were revered for the vows they took and strove daily to keep, their religious achievements flourished under the shadow of the earlier ideal of sainthood. Even the most devoted consecrated lives that ordinary believers acclaimed still struggled to justify themselves before the martyr's most favorable judgment. Two well-known examples from the hagiographical tradition make this point.

In Athanasius's Life of Antony, we see an early expression of this eschatological anxiety. Written shortly after Antony's death in 356, the text records the ascetical achievements of one of the first and certainly one of the the most revered Egyptian monks. Athanasius portrays Antony's lifelong denunciation of fleshly desire as a context for his devoted contemplation of God. At every turn in this difficult journey, Antony faced temptations of the mind and the body, and even physical beatings at the hands of the devil, who was intent on bringing the monk to ruin. Antony's steadfast commitment to the ascetical life led his fellow Christians to regard him as a living saint. Some expressed their admiration by following his example directly, retreating to the desert to live the hermit's life. Others simply wanted to be near him, as though sharing his physical presence placed them in the ambit of sacred power. In the narrative, this pious attention from the faithful proved a distraction to Antony, who fled from all this enthusiastic notice by making an abandoned fortress his monastic cell and living in it alone for 20 years. The faithful were undeterred by Antony's desire for solitude and kept watch outside the fortress, initially content just to be near the holy man. But eventually his admirers grew impatient and "tore down and forcefully removed the fortress door." Antony, Athanasius writes, "came forth as though from some shrine, having been led into divine mysteries and inspired by God." He continues:

And when they beheld him, they were amazed to see that his body had maintained its former condition, neither fat from lack of exercise, nor emaciated from fasting and combat with demons, but was just as they had known him prior to his withdrawal. The state of his soul was one of purity. ... He maintained utter equilibrium, like one guided by reason and steadfast in that which accords with nature. ${ }^{20}$

And "through him," Athanasius testifies, "the Lord healed many of those present who suffered from bodily ailments; others he purged of demons.... He consoled many who mourned, and others hostile to each other he reconciled in friendship." 21

${ }^{20}$ Athanasius, The Life of Antony and the Letter to Marcellinus, trans. and intro. Robert C. Gregg, pref. William A. Clebsch (New York: Paulist, 1980) 42.

${ }^{21}$ Ibid. 
Athanasius clearly draws connections here between Jesus' resurrection and Antony's appearance to the crowd. Antony's ascetical regimen seems already to have produced a resurrected body in this life, one that has banished the traits of deathliness and that, by presence alone, is a conveyer of graceful, healing power. Antony is Christ-like by virtue of an extraordinary discipleship forged in ascetical sacrifice. But even though this scene offers imaginative allusions to Jesus' resurrection, Athanasius does not describe the fortress simply as a tomb but as a shrine. The more direct comparison that the text offers is one that measures the new ascetical saint against the high standard of the martyr, pressing the case for Antony's worthiness as holy man. Amazingly, Athanasius portrays Antony as though he were a living relic, and so an animated version of the martyr's charismatic corpse. "Buried" in the shrine, he is yet salvationally present to the faithful who seek him, as were the relics of the martyrs to earlier generations. Like the martyr, he brings physical and spiritual healing to those who approach him in need. Athanasius undoubtedly believes that Antony's remarkable discipleship has already garnered God's favorable judgment. He possesses the spiritual stature of the martyr even though he did not suffer a martyr's death. And yet, Athanasius's justification is riddled with eschatological anxiety, the fear that even Antony falls short when measured against the martyr's established authority.

Athanasius expresses this anxiety even more directly in his narrative. During the persecution of Egyptian Christians under Maximinus in the early fourth century, Antony placed himself in danger by ministering to those who were arrested and sentenced to imprisonment or forced labor. Athanasius describes Antony's bravery in standing by the victims as a source of wonder to the prefect who enforced the writ of persecution. Athanasius, though, does recognize that Antony's witness fell short of the ultimate sacrifice and feels the need to explain: "For, as I said before, he also prayed for martyrdom. He seemed, therefore, like one who grieved because he had not been martyred, but the Lord was protecting him to benefit us and others, so that he might be a teacher to many in the discipline that he had learned from the Scriptures."22 Athanasius confronts the problem of the martyr's threatening judgment by offering a more direct comparison between martyr and ascetic and an apology for Antony's way of life: "When finally the persecution ended, and Peter the blessed bishop had made his witness, Antony departed and withdrew once again to the cell, and was there daily being martyred by his conscience, and doing battle in the contests of faith. He subjected himself to an even greater and more strenuous asceticism, for he was always fasting." 23 Athanasius invokes 
martyrdom here as a metaphor for the ascetic's struggle with sin, which, given the facts of Antony's life, is the only kind of martyrdom he can achieve. The use of the metaphor testifies to the martyr's authority and to Athanasius's judgment that, to be a holy man, Antony must wear the martyr's mantle in some way.

This same eschatological anxiety is also evident in a much later hagiography, Bonaventure's Life of Francis. Written in 1260, the longer version of Francis's life hails the saint as a person of "extraordinary sanctity" and as "an example for those who would be perfect followers of Christ." ${ }^{24}$ Seven centuries after Francis's death, Pope Pius XI would officially grant him the title alter Christus, "another Christ," but Bonaventure already assumes this to be so, and his account of the life did much to earn Francis the formal papal honor. Bonaventure describes the saint as a remarkable imitator of Jesus, even to the point that Francis performed many of the miracles that Jesus worked in the Gospels, including the changing of water into wine. ${ }^{25}$ Identification with Christ, Bonaventure tells the reader, was Francis's ascetical goal. He "longed to be totally transformed into him by the power of ecstatic love" and worked ardently at this task by reliving Jesus' 40 -day fast in the desert-"secluded in a lonely place, shut up in a cell, with as little food and drink as possible, fasting, praying, and praising God without interruption." ${ }^{26}$ But as much as Christ remains the paradigm for Francis's spiritual striving in the text, it is interesting to see how Bonaventure regards the martyrs as a measure of Francis's saintly quest, and a threatening measure at that.

Francis's approach to the religious life can only be described as competitive, an observation that Bonaventure specifically offers. He notes that, "whenever he saw anyone more poorly dressed than he, Francis immediately censured himself and roused himself to imitate him, as if he were competing in a rivalry over poverty and feared to be beaten by another."27 Always venturing more in this competition, Francis set out for Syria in his sixth year of ascetical practice. His goal, Bonaventure states, was "to preach penance and the Christian faith to the Saracens and the infidels."28 His motivation for making this journey was to meet the high standard set by the tradition's earliest saints, for Francis took up this quest "burning with a desire of martyrdom,"29 presumably a possible consequence of preaching the gospel in the Muslim world. Bonaventure describes this same

${ }^{24}$ Bonaventure, Bonaventure: The Soul's Journey into God, The Tree of Life, The Life of Francis, trans. Ewert H. Cousins, pref. Ignatius Brady (New York: Paulist, 1978) 181.

25 Ibid. 225-26.

${ }^{27}$ Ibid. 244.

26 Ibid. 263-64.

${ }^{29}$ Ibid. 266.

28 Ibid. 266-67. 
desire as a constant companion to Francis on his evangelical mission: "But the fruit of martyrdom had so attracted his heart that he desired a precious death for the sake of Christ more intensely than all the merits from the virtues." ${ }^{30}$ We see the same motivation ascribed to Francis in a return to the Middle East seven years later in the midst of the dangers of the fifth Crusade. Undeterred by threats to the lives of Christians, Francis is portrayed by Bonaventure as an "intrepid knight of Christ ... not terrified by the fear of death, but rather drawn by desire for it." ${ }^{31}$

The climax of Francis's hagiography occurs in his reception of the stigmata in the last years of his life. Yet, it is interesting to see how this profound event unfolds under the specter of the martyr's extraordinary sacrifice. Bonaventure depicts Francis's holiness as a context for this remarkable act of divine favor, and judges his holiness by the achievements of his ascetical life. The "man filled with God," Bonaventure testifies, "understood that just as he had imitated Christ in the actions of his life, so he should be conformed to him in the affliction and sorrow of his passion." ${ }^{32}$ Even though Francis's lifelong asceticism has brought him the recognition of his religious culture, in his (and Bonaventure's) mind a yet higher standard of Christic imitation set by the martyrs judges even the most excellent performance of virtue. "And although [Francis's] body was already weakened by the great austerity of his past life and his continual carrying of the Lord's cross, he was in no way terrified but was inspired even more vigorously to endure martyrdom." ${ }^{33}$ Bonaventure feels compelled to justify Francis before the martyr's complete sacrifice, even as he describes the exact moment that Francis received the stigmata and shared intimately in the wounds of the cross: "Eventually he understood by a revelation from the Lord that divine providence had shown him this vision so that, as Christ's lover, he might learn in advance that he was to be totally transformed into the likeness of Christ crucified, not by the martyrdom of his flesh, but by the fire of his love consuming his soul."34

It is strange to find that the martyrs proved to be such a threat to the tradition's later ascetical saints, even to extraordinary figures like Antony and Francis. But so seems the evidence, at least as it is conveyed in the judgments of Athanasius and Bonaventure, which are separated in time by nearly a millennium. That Athanasius and Bonaventure place their ascetical heroes in competition with the martyrs is testimony to the martyr's remarkable achievement and an expression of the eschatological anxiety that this achievement stirs in them as they work ardently to fashion their own. Our understanding of the late medieval development of the doctrine

30 Ibid. 267.

32 Ibid. 304.

${ }^{34}$ Ibid. 305-6.
31 Ibid. 268.

${ }^{33}$ Ibid. $304-5$. 
of purgatory, however, requires us to attend to the temporal dimension of this competition, particularly to the different ways in which saintly acts unfold in time.

The martyr's defining saintly act transpired in a moment, or, to be exact, in however short a time it took for the sufferings of martyrdom to culminate in death. The martyr's saintly act was threatening not only because it imitated the Savior's death so closely but also because the clarity of such imitation could shine forth in a single moment in which the ambiguities of spiritual struggle and sinful weakness were eternally banished. Even if their lives were remembered as extraordinarily virtuous, the martyrs distinguished themselves as saints instantly in the act of faithful dying. The definitiveness of this temporal moment, and not only the action that filled it, stood as a challenge to the ascetical model of saintly practice that flourished in the tradition after the age of persecution. Those aspiring to ascetical sainthood found themselves in a spiritual competition with the martyrs, a competition that in principle they could not win in the course of their lives because of two insuperable obstacles. First, the martyr's consummate sacrifice transcended imitation since ascetical aspirants soon flourished in a Christian culture that celebrated rather than threatened their lives. Second, the singularity of the martyr's saintly act was compressed into a brief temporal moment that then became timeless. Spiritual achievement so impressive that it could be accomplished at once earned an equally instant judgment accompanied by the certainty of saintly status. By comparison, the ascetical path to sainthood was lifelong and fraught with the uncertainties of self-doubt and moral failure, to say nothing of constant and wanting measure against the standard of martyrdom. Even in the hagiographies of living saints like Antony and Francis, whose spiritual achievement was widely acknowledged and celebrated by their contemporaries, temporal duration became a field of eschatological anxiety in which the most worthy ascetics continued to compete, always venturing more in order to secure the divine judgment they sought.

\section{COPING WITH THE ASCETICS}

In the Catholic imagination, purgatory is a multivalent place. Its sufferings are portrayed as extreme and mild, physical and psychological, as laden with guilt and as occasions of joy. This multivalence extends to the scholarly interpretation of purgatory. Philip Ariès, for example, calls attention to how purgatory mitigates the power of hell. ${ }^{35}$ Barbara Newman highlights gender issues in the interpretation of purgatory by raising inter-

${ }^{35}$ Ariès, Hour of Our Death 151-54. 
esting questions about the religious aspirations of medieval women. ${ }^{36} \mathrm{Re}-$ minded of Dante's poetic celebration of the desire for heaven on the part of purgatorial sufferers, Jacques Le Goff ponders whether another tenable alternative to his argument might very well be that purgatory was "more a pre-eternity than a post-existence." 37 Without any claim for interpretive exclusivity, I follow a lead offered by Pierre Chaunu in his intriguing study of early modern attitudes toward death in the city of Paris. Here Chaunu argues that purgatory negotiates the problem of duration, not only in its metaphysical state as a temporal realm but also, and more importantly, in the character of its temporality as an extended time defined only by the indeterminate events of the Second Coming and the Last Judgment. ${ }^{38}$ Thus I include this notion of duration in my discussion of eschatological anxiety in Catholic discipleship.

As much as historians disagree about when exactly to date the appearance of the doctrine of purgatory, a scholarly consensus has emerged that an explicit and widespread belief in purgatory did not develop until the late Middle Ages. That belief was accompanied by the first theological reflections on the place of purgatory in the life of faith and even the first speculations on what life in purgatory was like for the souls who suffered there. The doctrine received formal ecclesiastical approval, with varying degrees of explicitness, at the Second Council of Lyons (1274), the Council of Florence (1438), and the Council of Trent (1563). Even though there is mention of otherworldly purgation in Augustine's City of God and a host of purgatory-like ideas in the writings of the ancient Church Fathers and in early medieval texts, the evidence strongly suggests that the doctrine of purgatory developed relatively late in the Catholic tradition.

It is interesting to consider why this was so. Why did a belief like purgatory, which enjoyed popularity for centuries after its appearance, emerge rather late in the tradition? This question is different from Le Goff's, which asks what new and particular social circumstances gave rise to the new belief and all the practices that attended it. Posing the question of origin with appeal to the tradition considers the appearance of new or, at the very least, more explicit religious beliefs and practices within a larger network of meaning that they serve and promote through the behaviors of those who believe and enact them. This religious tradition, of course, is utterly

${ }^{36}$ Barbara Newman, "On the Threshold of the Dead: Purgatory, Hell, and Religious Women," chap. 4 of From Virile Woman to WomanChrist: Studies in Medieval Religion and Literature (Philadelphia: University of Pennsylvania, 1995) 108-36.

${ }^{37}$ Le Goff, Birth of Purgatory 359.

${ }^{38}$ Pierre Chaunu, La mort à Paris: XVIe, XVIIe et XVIIIe siècles (Paris: Arthème Fayard, 1978) 83-112. 
woven into all the other strands of culture, and so much so that only the most artificial abstraction could configure it idealistically, or as something sui generis. And yet, as a dimension of culture with an enduring coherence of its own, a religious tradition offers a framework of explanation that is an important perspective to consider in accounting for any historical etiology, especially those that concern thematically religious instances of origin, like the burgeoning late medieval belief in and practice of purgatory. If purgatory was a widespread and meaningful belief for Catholic Christians from the 12th through the 20th centuries, the question of why its development came so late in the tradition is at least as meaningful as the question of why purgatory seems to have largely disappeared from Catholic belief and practice in our own day. I now consider how the traditional trajectory of what Peter Brown calls the "peccatization" of the world and what I have called the "quotidianizing" of judgment made its way into medieval Catholicism in a way that negotiated the eschatological anxiety of the laity.

I have noted that the martyr's instantaneous virtue and judgment set a standard of discipleship that challenged hagiographers as different as Athanasius and Bonaventure. As much as these biographers were convinced of the saintly stature of their exemplary ascetics, they still worried that their spiritual heroes fell short of the martyr's measure and did all that they could to justify their saint in the way they told his story. This tension in the hagiographies may or may not have represented the actual feelings of Antony and Francis themselves. The writings only allow us to make judgments about the views of their authors. Later Christians counted both Athanasius and Bonaventure in the company of the saints. But in their own day, the hagiographers were ascetics struggling with the eschatological anxiety instigated by the martyr's consummate holiness and which they expressed so clearly in their literary defenses of their ascetical masters. Martyrs and ascetics were spiritual rivals, though only, of course, in the ascetic's retrospective judgment. As the consecrated life became the shape of extraordinary discipleship after the age of persecution, the martyr's example stood before the ascetic's vows as a practically unreachable goal. Every moment in the ascetic's life offered an occasion for reminder that the ascetic was not a martyr, and so less holy than the martyr. Time so considered defined the ascetic's life as a negative field of judgment. And yet, the ascetical lifetime also offered a means of negotiating this eschatological anxiety. Every moment in the ascetic's life offered an occasion for the imitation of Christ. None of these acts could compete with the martyr's single act, offered to God in the moment of complete sacrifice. But all these acts together, filling the longer temporal duration of an ascetical lifetime, could and did justify the holiness of the monastic life and, in extraordinary cases, monastic saintliness. Time so considered defined the ascetic's life as a positive field of judgment. 
The development of the doctrine of purgatory can be considered with regard to this background, though now as a stage for the relationship between the ascetic and the layperson. In his study of relations between the living and the dead in the Middle Ages, Patrick Geary offers a succinct description of the role of ascetics in their wider social world:

Monastic communities performed two religious functions vital to medieval society at large. First, clerics prayed for the salvation and well-being of the local population, particularly their benefactors and supporters. Inclusion in the prayers of the religious during one's lifetime and after one's death was a vital concern to a population obsessed with the insecurity of this life and the uncertainty of the next. Second, through the divine office, the Mass, and the cult of the saints whose relics were honored in the community's church, the regular clergy fulfilled the ritual actions necessary to keep the spiritual powers benevolently disposed toward human society. ${ }^{39}$

Monks provided spiritual goods for the laity. But, as Geary notes, laypersons provided for the clerics as well, by contributing directly or indirectly to the financial support of their communities. This exchange, however, was far from equal. The clerics mediated the power of eternal life to an eschatologically anxious culture. Clerics possessed this power by virtue of their commitment to a consecrated life that, at least in principle, filled time with extraordinary acts of discipleship. This difference in vocation, and all that attended it, stirred a different sort of eschatological anxiety in the wider reaches of the Christian population. The layperson's eschatological anxiety was not measured by the martyr but by the ascetic, who now stood in medieval culture as a living standard of Christian devotion, of a life that was worthy of heavenly reward.

If the martyr arose in the ascetic's judgment as a daunting spiritual competitor, then a certain kind of competitiveness also characterized the layperson's relationship with the ascetic. Unlike those who vowed a consecrated life, laypersons did not choose to enter the fray of extraordinary discipleship. Rather, they found themselves in a system of relationships that I call a "hierarchy of discipleship" defined by the valued distinction between the clerical life and their own. Within this stratified spirituality, a forced competition entered the religious imagination of the layperson that was simply a product of vocational difference. Time proved to be an important dimension of the competitive relationship between the ascetic and the layperson, just as it did in the relationship between the ascetic and the martyr. The ascetic's entire consecrated life provided a temporal trajectory within which a saving judgment could be earned. This extended time for virtue negotiated the martyr's instantaneous judgment. The ascetical

${ }^{39}$ Patrick Geary, Living with the Dead in the Middle Ages (Ithaca, N.Y.: Cornell University, 1995) 95. 
lifetime validated its spiritual worthiness through a duration filled with virtuous quantity that competed as best it could with the martyr's singular act of imitative quality. This same duration, though, validated the ascetic's spiritual worthiness with regard to the lower end of the hierarchy of discipleship. If, as Peter Brown claimed, the peccatization of the world in early Catholic Christianity compressed the spiritual portfolio of judgment into all the deeds of a lifetime completely embraced in the believer's hour of death, then the consecrated life, believers assumed, was especially well positioned to meet the demands of divine judgment. This is not to say, of course, that believers did not encounter abominably sinful ascetics and remarkably saintly laypersons in their day-to-day experience, and take account of these anomalies in their eschatological expectations. Yet, the vocational difference between ascetics and laypersons defined a competitive field on which, it was assumed, the ascetic had an overwhelming eschatological advantage. This advantage worked to soothe the ascetic's anxiety before the martyr, just as much as it provoked the anxiety of the laity before religious lives judged in principle to be more.

The relations in the hierarchy of discipleship described here first appeared as the age of persecution ended in the early fourth century and the ascetic took the place of the martyr as the paradigmatic holy person in the living experience of the church. The development of the monastic movement in the early Middle Ages and the proliferation of religious orders throughout medieval times instantiated the hierarchy of discipleship in the Christian worldview, an outlook that embraced not only this world but also, I would suggest, the world to come. Perhaps the doctrine of purgatory developed slowly and came to popular acceptance rather late in the tradition, partially at least because its development was a function of the institutionalization of monasticism, the working of the hierarchy of discipleship into the Christian order of things, and, with that hierarchy, the various kinds of eschatological anxiety that it stirred in the lives of ascetics and laity. Considered from this perspective, the birth of purgatory negotiated the eschatological anxiety of the laity by finding a solution to the problem of competitive judgment in temporal duration. In a manner similar to the ascetic's lifelong lengthening of the temporal field of competition with the martyr, belief in purgatory lengthened the layperson's temporal field of competition with the ascetic. ${ }^{40}$ Purgatory allowed the laity to cope with the

${ }^{40}$ A pious instructional book from the early 20th century explains the duration of purgatory in relation to the martyr's instantaneous judgment: "With God's grace and man's faithful labour, all these mischiefs can be undone in the end. But we cannot wonder if it takes a very long time, and is still uncompleted when death comes. ... To our seeing, the new making of our souls is a task for a thousand years. But the power and the mercy of God can do it in an instant. The Church sings of 
eschatological anxiety engendered by the consecrated life by extending the time for a satisfactory judgment on one's life into a temporal realm beyond death, one limited in duration only by the end of time and the Last Judgment-a time that could be described, quite literally, as "all the time in the world."

This vast purgatorial horizon of time allowed for the forced competition between ascetics and the laity to be conducted on a more level playing field, one that stretched the believer's lifetime of judgment into the otherworld so that time could serve the believer in a way that it may not have in the course of earthly life. In some respects, the effect of this temporal lengthening allowed the layperson's life to be more like the ascetic's, in much the same way that the ascetical paradigm of the saintly life allowed the ascetic to be more like the martyr. We see this otherworldly "asceticizing" of the layperson's purgatorial life in several ways.

First, and minimally, purgatory conflated the layperson and the ascetic in their shared need for purgation after death. Accounts of purgatory abound in their descriptions of the need for purgatorial suffering on the part of monks and nuns. The late twelfth-century French version of St. Patrick's Purgatory by Marie de France charts the otherworldly journey of the Irish knight Owen, who, though still alive, enters purgatory to witness its terrible sufferings. After the tortures of purgatory are detailed in scene after scene, a narrator's voice enters the text to deliver a homily on the penitential sufferings that compares them to the sufferings of the monastic life:

Not even cloistered monks

(Who think they lead a harsh life

On account of their confinement)

Know what sort of pains and torments

Are in the places we have described

And set before you. ${ }^{41}$

the martyrs fitted for heaven Mortis sacrae compendio, by the crowded action of their holy death. For what God does slowly through our years of prayer and self-denial and suffering is still God's work, not ours" (J. B. McLaughlin, O.S.B., Purgatory or the Church Suffering, intro. Patrick J. McCormick [London: Burns, Oates, \& Washbourne, 1929] 8). And, in a similar vein: "The soul's love for [God] could be raised to such intensity as to burn out instantly all other loves, desires, attractions. This we believe God does in the souls of his martyrs, who lay down their lives for him with a love than which no man hath greater. But in other souls there is no reason to suppose such a miracle of grace. It is fitting that they should go through the long agony of painfully detaching their souls from the wrong affections to creatures which they have willfully and persistently encouraged to take root in their souls" (ibid. 29-30).

${ }^{41}$ Marie de France, Saint Patrick's Purgatory: A Poem by Marie de France, trans., intro., notes Michael J. Curley, Medieval and Renaissance Texts and Studies 94 (Binghamton, N.Y.: Center for Medieval and Early Renaissance Texts, 1993) 127. 
The chiding tone directed toward the monk assures the layperson that even the most rigorous forms of ascetical self-denial pale before the sufferings of purgatory that nearly all, in the end, will share. In a letter written sometime between 1173 and 1179, Hildegard of Bingen relates the extraordinary sufferings of a soul in purgatory. Burning in a house consumed by a "fierce fire," the punished soul "glowed like red-hot iron," its sufferings greatly multiplied by stinging scorpions and devouring boars. Hildegard ends her account of the vision by observing that this soul would not be lost to hell in spite of its great sins, because "while living in the body, it had been disciplined by its superiors in accordance with the Rule, and, by God, through physical infirmity." ${ }^{42}$ The soul enduring such punishments is that of a sinful ascetic.

This same minimal conflation also occurs in Dante's purgatorial sojourn. In Canto XVIII, Dante discovers the remarkable penance allotted for the sin of sloth-the guilty must run in purgatory without pause. Among the moving throng is a soul who apologizes to Dante for his apparent rudeness in conversing on the run and who acknowledges both his guilt in deserving such punishment and his identity as the Abbott of San Zeno at Verona. ${ }^{43}$ Canto XIX relates even more prominent ascetical penance in the realm of avarice where Dante encounters Pope Adrian V, who lies prostrate on the ground, bound hand and foot, his eyes forced to contemplate the material object of his sinful desire. When Dante kneels beside him out of respect for his ecclesiastical station, Adrian demurs, "'Straighten your legs, rise up, brother,... do not err: I am fellow-servant with you and with the others unto one Power." 44

As much as these texts conflate the ascetic and layperson by stressing the sinfulness of ascetics, few depictions of purgatory undermine the hierarchy of discipleship more than the 15th-century $A$ Revelation of Purgatory by an unknown woman visionary. The author imagines the ecclesiastical hierarchy in purgatory, with all groups distinguished and suffering in particular ways. Married men and women are pierced with flaming goads by devils who then force-feed them pitch and round out the punishment by drawing them apart, "bone from bone." ${ }^{45}$ Single men and women are roasted on

${ }^{42}$ Hildegard of Bingen, The Letters of Hildegard of Bingen, 3 vols., trans. Joseph L. Baird and Radd K. Ehrman (New York: Oxford University, 2004) 3:16364.

${ }^{43}$ Dante Alighieri, The Divine Comedy, 6 vols. in 3, trans. Charles S. Singleton, Bollingen 80 (Princeton, N.J.: Princeton University, 1973) 2/1(Purgatorio) 194-97, at 197 (Canto XVIII, 88-127).

${ }^{44}$ Ibid. 206-10, at 209 (Canto XIX, 98-145).

${ }^{45}$ A Revelation of Purgatory by an Unknown, Fifteenth-Century Woman Visionary: Introduction, Critical Text, and Translation, trans. and intro. Marta Powell Harley (Lewiston, N.Y.: Edwin Mellen, 1985) 129. 
spits and consumed by "adders, snakes, and toads," and then dragged through the fire on sharp hooks by devils who complete the torture by dismembering their hearts and genitals. ${ }^{46}$ This account of the suffering of laypeople, though, comes later in the text. The author begins by observing that in the fire of purgatory is "every kind of pain" imaginable and "every sort of Christian man and woman living here in this world, no matter what rank they were. ${ }^{, 47}$ Of all these ranks, clerics are placed first in the catalogue of suffering, not only in their order of appearance in the text but also in the degree of their penitential pain. "But among all the pains that I saw of all men and women," the visionary claims, "... it seemed men and women in the ministry of the Church had the greatest pain in that sight." 48

Having set the scene of clerical suffering, the visionary immediately recounts the appearance of a soul named Margaret, "a sister living in a religious house" who pleads for intercessory prayers and masses to end her purgatorial suffering. The suffering soul is described as "marked with severe wounds, as though she had been rent with combs," and as "wounded and torn." Her heart is rent with "a grievous and horrible wound; from it there came sparks, and from her mouth a flame."49 The visionary details Margaret's terrible suffering at the hands of devils who align their vile torments with particular sins she committed in life. Turning her attention to the suffering endured by all in purgatory for particular sins, the visionary warns that lechery "was the [sin] most severely chastised, and especially that of men and women of Holy Church, whether they were religious or secular." 50 Devils wield razors to mangle the "heads and prelates of Holy Church," whose suffering reaches a crescendo as they are eviscerated for betraying their priestly vows. ${ }^{51}$ And yet, even among the suffering clerics there are further distinctions to be made:

It seemed that religious men and women had a hundred times more pain than secular priests and secular women had, for they were cast onto cruel wheels and turned about with intense fire, and adders, snakes, and devils were always around them. And the devils turned the wheels so fast that I could not see them, but very horribly they cried, as if all the world had cried at once. And this pain, father, had religious men and women and prelates of Holy Church-more pain than secular priests or secular women. ${ }^{52}$

The more rigorous the ascetical vows, the more intense the purgatorial punishment, an imaginative depiction of the "third place" that utterly in-

46 Ibid.

${ }^{48}$ Ibid.

50 Ibid. 123.

52 Ibid. 126.
47 Ibid. 113.

49 Ibid. 113-14.

${ }^{51}$ Ibid. 125-26. 
verts the earthly hierarchy of discipleship and narrows the judgmental distance between ascetics and laypersons. ${ }^{53}$

Purgatory allowed the conflation of ascetics and laypersons in another, more important way that drew on the Christian belief in the productive power of suffering. In this regard, the textual evidence suggests that the layperson becomes like the ascetic, and, even more, can become an ascetic through purgatorial suffering.

Striking examples of this ascetical transformation occur in Marie de France's St. Patrick's Purgatory. The local bishop counsels the knight Owen to prepare for his journey to the underworld by placing himself "Among the good men of a monastery, / Or among the canons of a convent; / Then he [Owen] would be more certain to accomplish his purpose." ${ }^{54}$ A prior who keeps the purgatorial gates, which are an inner door of an Irish church, insists that Owen ready himself by remaining in the church "for fifteen days, / Fasting and praying, keeping vigils, / And performing acts of mortification." 55 The layperson must act like a monk in order to face the test of expiation. As Owen enters purgatory and wanders "far underground" through ever-increasing darkness, he breaks into a "winter light at dusk" that reveals a

palace [that] had all around it

One continuous wall,

Constructed of columns, arches,

Vaults and wandiches.

It resembled a cloister,

Suited for men of religion. ${ }^{56}$

The palace seems to be an anteroom to heaven, a place of transition between purgatory and eternal glory, though it is clearly still in purgatory since a man whom Owen meets inside warns him to "conduct yourself bravely, / Or you will perish here" amidst the sufferings that the reader is about to encounter outside the palace walls. The speaker is described as

${ }^{53}$ Michel Vovelle argues that the flourishing of belief in purgatory truly takes place in the late 14th and 15th centuries, when images of the "third place" begin to proliferate in art. Several images that he cites as evidence express this hierarchical inversion by depicting the purgatorial suffering of clerics. The late 14th-century "Le brévaire parisien" is a decorated letter that portrays a bishop sharing the pain of purgatorial fire with laypersons. The 18th-century Spanish altarpiece from San Pedro da Mezquita includes sculptures of a bishop and a priest, each in his own bouquet of purgatorial flames. Michel Vovelle, Les ames du purgatoire, ou le travail $d u$ deuil (Paris: Gallimard, 1996) 47, 182.

${ }^{54}$ Marie de France, Saint Patrick's Purgatory 75.

55 Ibid. 71.

${ }^{56}$ Ibid. 81. Clearly "wandiches" refers to physical features or trimmings in the palace, but the exact referent of the word is unknown. See Ibid. n. 9. 
"the master and prior" of 14 other men who together greet him as he enters. The 15 receptionists are portrayed as "Recently shaved and tonsured / And dressed in white vestments /.../ Appearing to be men of religion." ${ }^{57}$ That the monks are "recently" tonsured is especially interesting. They may be so for the unlikely reason that they all died recently as novices and have quickly found their way to glory, for it is clear in the text that they are in a state of beatitude beyond the sufferings of purgatory. Another, more likely, explanation is that their recent tonsuring is the mark of their expiation through purgatorial suffering, which, in turn, would suggest that the successful negotiation of purgatory can bring the layperson to the ascetical vocation.

The text does not suggest that expiation always has this effect. In fact, later in the account, after Owen has witnessed scene after scene of purgatorial torture, he enters the earthly paradise that Adam and Eve inhabited before the Fall. There he sees all who have met the measure of purgatory and who, in the glory and happiness of completed penance, await ascent to the celestial paradise above. The layperson is mentioned, which suggests that purgatory does not end for all with the profession of monastic vows. Yet, even there the layperson moves in the overwhelming company of ascetics:

He also observed religious folk / Walking in procession. / It seemed to him that no one had ever seen / Such a splendid procession / Anywhere or at any time, / Nor one so nobly arranged. / He saw forms of men and images / Of every age, and likewise / Of every order. / Great was that company of folk. / All were differently attired, / According to their orders. / Some were dressed like archbishops, I Others like bishops, / One like an abbot, another like a monk, / A priest, a deacon, a canon, / Subdeacon, acolyte, / Or layperson, chosen by God. ${ }^{58}$

Clearly, this vision of purgatory's effects makes the ascetical path the standard of the saved state. The "layperson" is engulfed in the larger procession otherwise elongated by "religious folk." By walking with them, the layperson becomes like them, sharing in the decided majority of their redeemed glory and in a way that vocationally elevates the layperson to the status of one especially "chosen by God" (laie gent, a Deu eslite). ${ }^{59}$

A different version of this asceticizing of the layperson through suffering appears in what eventually became the developed theology of purgatory in the late Middle Ages. A clear and interesting illustration is Catherine of Genoa's Trattato on "Purgation and Purgatory," a transcription of her visions that appeared in 1522, twelve years after her death. Whereas Marie de France's St. Patrick's Purgatory presents a realm of infernal tortures and a hell itself for those whose sins are too great to make expiation and win

${ }^{57}$ Ibid. 83.

${ }^{59}$ Ibid. 132.

${ }^{58}$ Ibid. 133. 
release, Catherine imagines a very distinct "third place" whose sufferings are joyous because they bring a soul to the glory that God's favorable judgment has already secured for it. Catherine's description of these joyous sufferings could quite easily be read as an idealized portrayal of the monastic life, as an account of the same aspirations and goals that motivate ascetical renunciation. The souls in purgatory, she avers, are beyond the envy of comparison with their peers. "Such is their joy in God's will, in His pleasure, that they have no concern for themselves but dwell only on their joy in God's ordinance." 60 The souls exhibit the virtue of humility in community, all the while undergoing sufferings that are productive in bringing the soul to salvation. "This joy [in the desire for paradise]," Catherine states, "increases day by day because of the way in which the love of God corresponds to that of the soul, since the impediment to that love is worn away daily."61

Another testimony to the joyful sufferings of purgatory appears in the Probation of the late 16th-century Florentine visionary Maria Maddalena de' Pazzi. In one of her vivid and "lived" visions, transcribed by her Carmelite sisters, she wandered the convent garden as though it were purgatory, searching for her recently deceased brother. De' Pazzi's purgatory is a place of horrible tortures, and yet, when she finds her brother, she is pleased to find that his sufferings are delightful:

That night she was looking for her brother's soul. We understood that because, when she stopped, she said: “Oh, where is my little soul? Isn't he here among these ones?" And, when she found him, she was very happy and, showing a great joy, she spoke to him in a compassionate way: "Poor one, you suffer so much and are still very happy? You burn and are so cheerful?" 62

${ }^{60}$ Catherine of Genoa, Purgation and Purgatory; The Spiritual Dialogue, trans. and notes Serge Hughes, intro. Benedict J. Groeschel, pref. Catherine de Hueck Doherty (New York: Paulist, 1979) 71.

${ }^{61}$ Ibid. 72. It is interesting to see this same motif affirmed in a theological treatise of the early 20th century, as it largely was from Catherine of Genoa to the eve of Vatican II. Bernhard Bartmann, Purgatory: A Book of Christian Comfort, trans. Dom Ernest Graf, O.S.B. (London: Burns, Oates, \& Washbourne, 1936) 228-41. Just as interesting, though, is Bartmann's suspicion of imaginative accounts of purgatory offered by the likes of Catherine of Genoa and Marie de France. He dismisses private revelations as bearing too "striking a resemblance to pathological hallucinations" and strives for a doctrinally based theology of purgatory (ibid. 14). To the contrary, the argument presented here for the asceticization of purgatory finds the rich imagery of these late medieval accounts to be especially revealing.

${ }^{62}$ Maria Maddalena de' Pazzi, Probation, in Tutte le opere di Santa Maria Maddalena de' Pazzi dai manoscritti originali, 4 vols., ed. Ermanno Ancilloi, Claudio Maria Catene, and Pelagio Visentin (Florence: Nardini, 1960) 1:51, quoted in Armando Maggi, "Walking in the Garden of Purgatory: The Discourse of the Mind in the Probation of St. Maria Maddalena de' Pazzi," chap. 4 of Satan's Rhetoric: A Study of Renaissance Demonology (Chicago: University of Chicago, 2001) 170. 
Like Catherine of Genoa, Maria Maddalena de' Pazzi portrays purgatorial sufferings as fulfilling. Much in the manner of ascetical denial, they pave a path to spiritual perfection that brings the soul to God. Catherine presses this identification even further in her treatise. Just as the saintliness of the martyrs was defined by terrible suffering and just as the suffering of accomplished ascetics like Antony and Francis increased with their degree of holiness, so too does Catherine expect the soul in purgatory to know greater suffering as it advances in spiritual perfection. "Yet this joy [in God's overwhelming love]," Catherine insists, "does not do away with one bit of pain in the suffering of the souls in purgatory. As the soul grows in its perfection, so does it suffer more because of what impedes the final consummation, the end for which God made it; so that in purgatory great joy and great suffering do not exclude one another." 63

The record of Catherine's final vision makes the same connections between the ascetic and the soul in purgatory but does so more directly. Her concluding discourse describes the inner disposition of the soul in purgatory. And yet, from her words, it is difficult to distinguish between the comportment of the disembodied soul and the expected comportment of the monk or nun. Casting herself in the role of participant-observer, Catherine describes the purgatorial experience as her own, even though, as a visionary still alive, she has not passed through the death and divine judgment that would bring her into the state of purgation. "I see my soul alienated from all spiritual things," she claims, "that could give it solace and joy." In this desired state of spiritual acedia, the soul "has no taste for the things of the intellect, will, or memory, and in no manner tends more to one thing than to another." ${ }^{64}$ This detachment fosters and finally cul-

${ }^{63}$ Catherine of Genoa, Purgation and Purgatory 82. There is similar testimony to the joys of purgatorial suffering in a tract from the early 17th century by the French Jesuit Etienne Binet: "Wherefore under the notion of the Paradice of Purgatory, I understand, the excessive joyes of these captive souls, the incomparable acts of their will and understanding, and the continual favours shour'd down upon them from Heaven, even amidst their most cruel torments" (Etienne Binet, Purgatory Surveyed, or, A Particular Accompt of the Happy and Yet Thrice Unhappy State of the Souls There: Also of the Singular Charity and Wayes We Have to Relieve Them, trans. Richard Thimelly (also known as Richard Ashby) [London, 1663] 82-83). In addition to enlisting an ascetical paradigm to portray the joyful sufferings of purgatory, Binet invokes the highest standard of competition by comparing these sufferings to the martyrs': "Now will you clearly see, how the souls can at the same instant, swim in a paradise of delights, and yet be overwhelmed with the hellish torments of Purgatory? cast your eyes upon the holy Martyrs of Gods Church, and observe their behaviour. They were torn, mangled, dismembered, flead [flayed] alive, rakt, broyled, burnt, and tell me, was not this to live in a kind of Hell, and yet in the very height of their torments, their hearts and souls, were ready to leape for joy; you would have taken them, to be already transported into heaven" (ibid. 85-86).

${ }^{64}$ Catherine of Genoa, Purgation and Purgatory 85. 
minates in an abandonment of all "things," "places," and "persons" that detract from the spiritual path:

So vehement is the soul's instinct to rid itself of all that impedes its own perfection that it would endure hell itself to reach that end. For that reason the soul tenaciously sets about casting aside all those things that could give the inner self specious comfort. It casts out the least imperfection. Cutting itself off from all except those who seem to walk the way of perfection, the soul concentrates itself, preferring not to frequent places where those persons find their pleasure. ${ }^{65}$

Now, there are no "things" or "places" in Catherine's purgatory, as there are in other late medieval depictions of purgatory. And even though there are other "persons" in purgatory, Catherine began her treatise with the observation that the suffering souls in purgatory are unaware of each other as possible distractions from the consuming fire of God's purifying love. ${ }^{66}$ It would seem that Catherine has projected the goals and temptations of her own ascetical life into purgatory and has done so to the degree that ascetical renunciation has become the descriptive template for otherworldly purgation. That an ascetic would speak of the otherworld out of her own experience is hardly surprising. Yet, we cannot overlook the fact that Catherine understands herself to be describing the purgation of all the souls that are, or ever have been, or ever will be in purgatory. And since the vast majority of these suffering souls were laypersons in their earthly life, the vision of purgatory that she presents extends the field of ascetical aspiration and accomplishment to laypersons, thus allowing them to achieve in purgatory's extended time what they did not in the course of their lives.

All these ways in which the layperson is asceticized in purgatory diminished the competition between the layperson and the ascetic in the hierarchy of discipleship. The development of the doctrine of purgatory enabled the layperson to cope with the ascetical ideal of saintliness by extending the time in which divine judgment could be worked out for the layperson. The texts I have considered provided the layperson with the opportunity to affirm the integrity of the lay state by insisting that laypersons were no worse than, and sometimes even better than, ascetics as they suffered the purgatorial consequences of divine judgment. Even more, what became and remained the developed theology of purgatory from the time of Catherine of Genoa to the instructional manuals on purgatory from the early 20 th century ${ }^{67}$ enabled laypersons to participate in the ascetical

${ }^{65}$ Ibid. ${ }^{66}$ Ibid. 71.

${ }^{67}$ For example, Paul Wilhelm von Keppler, The Poor Souls in Purgatory: A Homiletic Treatise, trans. Stephen Landolt, ed. Arthur Preuss (St. Louis, Mo.: B. Herder, 1923) 65: "These Holy Souls enter upon their sufferings entirely of their own free will and persevere in them joyfully." 
life eschatologically by undergoing sufferings that were joyful and sanctifying. It is not surprising that laypersons like Dante and, probably, Marie de France would diminish the purgatorial difference between ascetics and believers like themselves, since that difference reflected their religious disadvantage before the divine judgment. More surprising, perhaps, is the fact that depictions of purgatory are largely the work of ascetics who seemingly acted against their religious self-interest by asceticizing purgatorial suffering in the ways I have considered. What might account for the willingness of ascetics like Hildegaard, Catherine, and so many others from the late Middle Ages to the mid-20th century to diminish their difference from the laity in their accounts of purgatory? Or, to pose the question from another angle, what advantage did ascetics find in their own contributions to the development of the doctrine of purgatory? Several answers together might contribute to an understanding.

First, one should not overlook compassion as a motivation for the willingness of ascetics to embrace all the dead into their state of hierarchical difference. As much as the hierarchy of discipleship encouraged ascetics to value their difference from the laity, the preeminent Christian virtue insisted on the love of neighbor which, in eschatological perspective, hoped for the salvation of all. Considered from a more particular emotional perspective, the conflation of laypersons and ascetics in purgatorial suffering allowed ascetics to imagine the assured salvation of their family members, from whom they had been distanced by their consecrated life. The purgatorial conflation of the lay and ascetical saints derived to some degree from a heartfelt commitment to the communion of the saints.

But ascetical self-interest also played a role in the development of the doctrine of purgatory. As much as ascetical compassion affirmed the latitude of the communion of the saints, that compassion was only one ingredient in a rich mixture of motivations that included the very strong desire to highlight the distinctiveness of the monastic vocation. The ascetical life provided a template for purgatorial suffering, since late medieval Christians simply assumed that the hierarchy of discipleship was true and that its redemptive standards had to be negotiated in one way or another. Once the late medieval theology of purgatory described its sufferings as joyful and spiritually productive, the "third place" became an otherworldly monastery that valorized the ascetical life as the surest path to glory. Purgatory's ascetical template allowed all its suffering souls to participate in the monastic life, even though all believers would have assumed that nearly all were the souls of laypersons. At the same time, this metaphorical widening of the monastic vocation in the afterlife strongly affirmed the authority of the ascetical life and its status in the competitive style of religion that itself 
led to the development of the doctrine of purgatory. ${ }^{68}$ In addition to this self-interest in the realm of religious mentalité, one should not overlook, even if it merits only a mention here, the financial benefits that accrued to clerics through almsgiving associated with the release of purgatory's suffering souls.. .

Finally, and most importantly for the argument offered here, purgatory allowed ascetics to cope with ascetics. We have seen that all ascetics were challenged by the high standard set for the religious life by the martyr's extraordinary example and that even the most influential hagiographiesthe stories of Antony and Francis-made every effort to justify the lives of the greatest ascetics before the ancient measure of martyrdom. Catholic culture, though, in any time and place is far more familiar with the lives of ordinary ascetics, those who have lived a life devoted to the church that, like most lives, is a mixture of virtuous and sinful deeds. Ascetics were subject to the same kind of eschatological anxiety that coursed through the merit system, an anxiety that for most was triggered much more by the tradition's saintly ascetics like Antony, Francis, and the founders of orders than it was by the martyrs. Purgatory offered ascetics the same advantage that it offered to laypersons-a wider field of time in which judgment could be adjudicated by productive suffering that drew the soul closer to the accomplishments of the greatest saints. ${ }^{70}$ For most ascetics, the differences

${ }^{68}$ An interesting example of this monastic authority on purgatory can be found in the work of Mechthild of Magdeburg (ca. 1208-ca.1282/94) who barters successfully with God for the release of its suffering souls. Mechthild's power over purgatory as a worthy ascetic is sufficient to secure the release of 1,000 souls at once. On another occasion, she wins the release of 70,000 souls by offering herself as ransom to God. Mechthild of Magdeburg, The Flowing Light of the Godhead, trans. and intro. Frank Tobin, pref. Margot Schmidt (New York: Paulist, 1998) 77-78, 123-24. The same motif is present in the work of Gertrude of Helfta (1256-ca.1301/ 02 ) who requests of God the release of suffering souls as numerous as the pieces of the fragmented communion wafer in her mouth. God grants her more. Gertrude of Helfta, The Herald of Divine Love, trans. and ed. Margaret Winkworth, intro. Maximilian Marnau, pref. Louis Bouyer (New York: Paulist, 1993) 183-84.

${ }^{69}$ Any number of studies are instructive on this point, but especially helpful are Jacques Le Goff, Your Money or Your Life: Economy and Religion in the Middle Ages, trans. Patricia Ranum (Chicago: Zone, 1990) 65-84; Carlos M. N. Eire, From Madrid to Purgatory: The Art and Craft of Dying in Sixteenth-Century Spain (New York: Cambridge University, 1995; Michelle Bastard-Fournié, "Le purgatoire dans la région toulousaine au XIVe et au début du XVe siècle," Annales du Midi (1980) 5-34.

${ }^{70}$ Eire offers an interesting illustration in his study of 16th-century Spanish bequests for the souls in purgatory: "No testator showed a more profound mixture of anxiety over the afterlife and confidence in the power of masses than Father Gregorio de Oviedo. Calling himself an 'unworthy priest,' this curate sat down with a notary while he was still healthy ... to write an obsessively detailed will ..., focusing entirely on the business of saving his soul from punishment.... Father Gregorio left his soul as heredera universal, requesting at least 875 masses ..., plus 
in the hierarchy of discipleship were as threatening as they were to laypersons and so required the balm of purgatorial time in which differences between believers mattered less, judgment extended beyond death, and, as I will consider in my concluding section, personal virtue that had mattered so much in the competitive religion of earthly time now mattered not at all.

\section{COMPETITIVE RELIGION IN ESCHATOLOGICAL PERSPECTIVE}

Purgatory's multivalence achieved its otherworldly variety through a host of this-worldly interests. Interests defined by social change, class, finance, patronage and exchange, ecclesiastical politics, and the desire for justice all contributed to the origin and development of purgatory. Here I have proposed another layer of explanation that might be added to these and other possible causes, namely, anxious longings prompted by traditional belief in the hierarchy of discipleship. Purgatory temporally stretched judgment in order to negotiate the burden of religious competition in a peccativized Catholic culture, a burden centered in the aspirations of ascetics but borne by all the faithful. In this concluding section, I reflect theologically on the appearance and disappearance of purgatory in the eschatological imagination of Catholic believers. I have already considered the appearance of purgatory in all sorts of ways, though there is still one more important matter to explore. I have more thoughts regarding the disappearance of purgatory in the last 40 years.

One of the most interesting aspects of the late medieval theology of purgatory is the belief that the suffering souls are utterly passive with respect to their own state of remediation. They can do nothing to improve their condition, diminish their suffering, or shorten their time of purgation. Although they have been judged favorably by God and have been assured of the beatific vision, the suffering souls can do nothing on their own behalf to bring their final state of salvation to completion. Thomas Aquinas explained the formal metaphysics of this passivity as early as the 13th century. Souls separated from their bodies at death, he argues, are immutable, since in this state there is no bodily desire to change the soul's enacted disposition toward its ultimate end, whether toward eternal beatitude or toward eternal damnation. Beyond death, the soul dwells "in a state of rest in the end acquired,"71 an inactivity that characterizes the souls in purgatory as

certain other clusters of masses. In addition, he asked with customary redundance that after all the appropriate fees had been paid for these, the remainder of his estate 'all be spent in pious works and alms for my soul.... I want it all spent on masses, sacrifices, and pious works"' (Eire, From Madrid to Purgatory 193).

71 Thomas Aquinas, Summa Contra Gentiles, 4 vols., vol. 4, Salvation, trans. C. J. O'Neil (Notre Dame, Ind.: University of Notre Dame, 1975) 344. 
much as it does the saints in heaven and the damned in hell. ${ }^{72}$ This position accounts for the finality and unchangeability of God's judgment on every life immediately upon death. After all, if souls could change in their disposition toward their final end, then God's judgment could be undone. And yet, even though God's judgment cannot be undone in any of the three otherworldly places, purgatory is a realm where the soul's "state of rest" is as much a matter of its passivity as of its immutability.

Catherine of Genoa described the inactivity of purgatorial suffering in a manner that became authoritative for the later tradition. The souls in purgatory, she claims, dwell "only on their joy in God's ordinance, in having Him do what He will."73 "Content in God's will" and having none of their own, the souls only feel "sorrow over their sins"74 and lack any trace of ego or sense of competition with their fellow souls: "These souls cannot think, 'I am here, and justly so because of my sins,' or 'I wish I had never committed such sins for now I would be in paradise,' or 'That person there is leaving before me,' or 'I will leave before that other one.' ... Such is their joy in God's will, in His pleasure, that they have no concern for themselves." 75 In Catherine's vision, the soul relinquishes itself to its suffering, which it "willingly accepts as a mercy." ${ }^{, 76}$ God is utterly the agent of the soul's purgation. "In so acting," she testifies, "God so transforms the soul in Him that it knows nothing other than God; and He continues to draw it up into His fiery love ... [where it] feels itself melting in the fire of that love of its sweet God." ${ }^{77}$ Insisting most pointedly on the soul's passivity in all this, Catherine confesses that "if we are to become perfect, the change must be brought about in us and without us; that is, the change must be the work not of man but of God." 78

Catherine's sensibilities on the passivity of the souls in purgatory prevailed throughout the later tradition, as far as the pastoral treatises of the early and mid-20th century. And yet, they did not prevail without contest. In his homiletic manual entitled The Poor Souls in Purgatory, Paul Wilhelm von Keppler, bishop of Rottenburg at the turn of the 20th century, insists that the souls in purgatory are "sentenced to a state of inactivity,

72 Ibid. 342.

${ }^{73}$ Catherine of Genoa, Purgation and Purgatory 71.

74 Ibid. 72, 75 .

${ }^{76}$ Ibid. 78.

75 Ibid. 71.

${ }^{77}$ Ibid. 79.

${ }^{78}$ Ibid. 81. This stance on the passivity of the suffering souls is affirmed in another 16th-century treatise by Cardinal William Allen, originally published in 1565: "Let us be circumspect therefore, and work while the day is here; for in the night or the next world sinners cannot help themselves, nor work one moment towards their own delivery or release" (Allen, Souls Departed: Being a Defence and Declaration of the Catholic Church's Doctrine Touching Purgatory and Prayers for the Dead, ed. T. E. Bridgett, C.Ss.R. [1565; London: Burns \& Oates, 1886] 160). 
which, however, is not a state of rest, but full of restlessness and an eager desire to act." ${ }^{\prime 79}$ Quite unlike Catherine, who touted the joyfulness of purgatorial passivity, Keppler ever accentuates the anguish of the souls in their inability to act, a motif that highlights the terrible loss of free choice in a religion that prizes meritorious action as the path to God. "In this state of passivity," Keppler declares, "the Poor Souls must feel doubly that painful want of the sacramental graces which were at their disposal during life. On earth, they were able to draw graces to themselves ... which would have... secured their immediate salvation." ${ }^{80}$ And now, in purgatorial time, such opportunities have vanished. Martin Jugie, a French theologian who flourished in the mid-20th century, agrees with Catherine that "there can be no question of merit after death" and that "after death, the soul does not change." 81 Jugie, though, was deeply suspicious of any explanation that would make purgatorial sufferings "a purification only," that to his mind would overlook the charitable actions of which the suffering souls are capable. Unlike Catherine, who maintains that the suffering souls are unaware of each other in the purifying power of divine love, Jugie sees purgatory as a region of "perfect fraternal charity." The "doing" of the souls, however, is limited to their praying for each other and for the living ${ }^{83}$ an activity that Jugie carefully laces with the passivity traditionally expected of the suffering souls. The prayers of the souls for others, he insists, lack "satisfactory value" or the possibility of merit and possess only "impetratory force, the proper efficacy of prayer considered in itself." For Jugie, the act of intercessory prayer in purgatory seems to be meager to the point of inaction. "It could be compared," he says, "to the gesture of a poor man who holds out his hand to a rich," 84 an analogy bent on asserting the

${ }^{79}$ Keppler, Poor Souls in Purgatory 76. The counterposition is clearly expressed in an earlier work by Henry James Coleridge, S.J., that is much closer to the typical view of passivity: "This calm and peace [of those who die in a state of grace] is not, in the case of the Holy Souls, a passing, but a permanent state, it lasts as long as they remain in the holy prison of Purgatory.... This peace of the holy state of Purgatory is as true and real an element in the condition of those souls ... as is the pain which they suffer and the length of time for which it may last" (Coleridge, Prisoners of the King: Thoughts on the Catholic Doctrine of Purgatory [London: Burns \& Oates, 1878] 164).

${ }^{80}$ Keppler, Poor Souls in Purgatory 78.

${ }^{81}$ Martin Jugie, Purgatory and the Means to Avoid It, trans. Malachy Gerard Carroll (Westminster, Md.: Newman, 1950) ii, 2.

82 Ibid. 11.

${ }^{83}$ Ibid. 41.

${ }^{84}$ Ibid. 42. A pious book from the early 20 th century shows his same tension between the passivity and activity of the suffering souls. The French Marianist $\mathrm{H}$. Faure portrays purgatory as a place of the "most profound, the most absolute peace" and its inhabitants as souls "in pressing need ... [who] cannot help themselves." And yet, he tells many stories of the souls interceding in earthly life on 
passivity of the penitent dead even in the midst of an argument for a residue of their activity.

In spite of their nuanced differences, these views on the passivity of the dead in purgatory consistently represent the same concerns. First and foremost, passivity in purgatory reflects the metaphysics of judgment that Aquinas articulated so clearly and that extends throughout all three dimensions of the otherworld. The eternal judgment of God constrains what the saved and the damned may do to the same degree that it constrains what they may be. In this traditional worldview, both eternal joy and eternal suffering are passive reactions to objective, supernatural conditions: respectively, the beatific vision and the torments of hell. Purgatorial passivity is an odd mixture of both joy and suffering, though both emotions here too are passive reactions to an immutable divine judgment still in a temporal process of being fulfilled. Second, the passivity of the souls in purgatory was vital to the practice of intercession on the part of the church militant, the faithful in life who enacted the values of ascetical culture on behalf of those in purgatory, including the suffering souls they assumed they would one day be. This passivity is important even to a theorist like Jugie, who is reluctant to relinquish all doing on the part of the suffering souls so that his purgatory retain some semblance of ascetical virtue while yet insisting with the tradition that purgatorial acts bring no merit to their agents.

In line with the argument presented here, I would suggest another dimension of purgatorial passivity that might aid in explaining both the origins of the doctrine and its recent disappearance. I have observed that a contributing factor to the development of the doctrine of purgatory may have been an effort on behalf of all the faithful to negotiate the competitive style of religion that gravitated around the ascetic's vocation. Purgatory, I have suggested, tempered the eschatological anxiety that permeated the Catholic culture of works by allowing the laity to be the ascetical sufferers that they were not and ascetics to be better ascetical sufferers than they were, all within a protracted time of judgment that lowered the bar-and the anxiety-of competitive religion. It would be interesting to consider that the passivity of the suffering souls is a further negotiation of this anxiety. As much as believers imagined purgatory as a supernatural monastery, they insisted, paradoxically, that it be portrayed as a place where the suffering souls were passive, unable to engage in the very behavior so competitively valued in the ascetical culture of Catholic Christianity. The

behalf of their devotees. Faure assumes, though, that these supernatural deeds are what we might call "passively" charitable actions, since they gain no merit. $\mathrm{H}$. Faure, The Consolations of Purgatory, trans. W. Humphrey Page (New York: Benziger, 1912) 81, 136, 165-71. 
passivity of purgatory affirmed the finality of divine judgment and fostered the ascetical values of the merit system by placing the suffering souls in need of intercession. But perhaps another layer of explanation is that the passivity of the suffering souls expressed the heartfelt desires of all believers for the end of competition and the quelling of the eschatological anxiety that issued from life in a peccativized world. Viewed from one angle, the passivity of purgatory anticipated the eschatological goal of heavenly rest. Considered, though, from the perspective of the development of doctrine, the passivity of purgatory expressed deep religious yearnings for inaction before a divine judgment already rendered and certain, even if not quite completed. Purgatory, so understood, was a place of struggle where the prevailing values of the entire system of belief were at once encoded and deconstructed, figuratively canonized and subverted, and, in the complexity of Catholic faith, both accepted and rejected.

Admittedly, this is a speculative interpretation, but one that might be justified if measured against the backdrop of the religious emotions competitively at work in Catholic Christianity. Thus regarded, the passivity of the suffering souls negatively conveys a rebellious desire that contributed to the development of the doctrine of purgatory. One way to test the coherence of this interpretation is to see how the doctrine of purgatory behaves in the absence of competitive religion. My hypothesis in this experiment must be that purgatory disappears where competitive Christianity is not the regnant style of faith. Two historical sites will serve as my testing grounds: the Christian culture of 16th-century Lutheran and Reformed Protestantism and one strain of post-Vatican II Catholic faith.

At first glance it seems as though my argument leads to the conclusion that the purgatorial desire for passive quiescence before the divine judgment was a seed of the Reformation that blossomed in the Protestant doctrine of grace alone. Certainly the Catholic belief in the passivity of the suffering souls and the Lutheran and Reformed belief in grace alone share a similar desire for a completed salvation where God's will prevails over all human initiative. Both beliefs acknowledge a state in which human helplessness surrenders before the divine judgment. At most, perhaps, one could understand the Lutheran and Reformed traditions to have expressed this general Christian desire in a host of determinately doctrinal ways. The differences between the Catholic and Protestant beliefs in passivity before God, though, are far more striking. The Lutheran and Reformed traditions moor this passivity in a doctrine of predestination, which places God's saving decision in eternity and makes all human actions worthless sins in the eyes of God. Catholic Christianity consistently has judged a strong doctrine of predestination to be religiously unacceptable. The medieval Catholic tradition rejected it first in the later work of Augustine, even as it 
accepted so many other features of Augustine's theology and person as utterly authoritative. And since the Council of Trent, modern Catholicism has decisively rejected the Protestant claim for eternal election, finding the doctrine's denial of the efficacy of free choice and natural responsibility for virtue as well as for sin to be inconsistent with its theological understanding of the human person. ${ }^{85}$ The Catholic yearning for passivity before divine judgment is not a desire for the certainty of the eternal decree but rather a desire for tranquility in the face of a particular kind of eschatological anxiety that has achieved its meaning in the context of moral, and even saintly, struggle.

The Reformation doctrine of grace alone provides a relevant point of comparison with the passivity of the suffering souls especially because its acceptance entailed the rejection of the competitive religion of the medieval Catholic tradition and the doctrine of purgatory that developed from it. The doctrine of sola gratia subverted the religious value of the ascetical life, which, I have shown, was the center and energy of Catholic competition. The Reformation understanding of grace as sheer divine gift meant that the ascetic's vocation was misdirected and, even more, an exercise in vanity, since grace could not be earned. That same judgment extended to the ordinary discipleship of the laity, who strove for a salvation measured by the ascetical standard. And finally, that same judgment extended to the doctrine of purgatory, which negotiated in complex ways the eschatological anxiety that attended this competitive style of religion. ${ }^{86}$ For Luther, "purgatory and all the pomp, services, and business transactions associated with it are to be regarded as nothing else than illusions of the devil, for purgatory, too, is contrary to the fundamental article that Christ alone, and not the work of man, can help souls." ${ }^{87}$ In the Institutes, Calvin puts his dismissal in the form of a rhetorical question: "But if it is perfectly clear from our preceding discourse that the blood of Christ is the sole satisfaction for the sins of believers, the sole expiation, the sole purgation, what remains

85 "The Decree on Justification, Council of Trent," in Decrees of the Ecumenical Councils, 2 vols., ed. Norman P. Tanner, S.J. (Washington: Georgetown University, 1990) 2:676, 672 (chaps. 12, 5).

${ }^{86}$ This disdain for purgatory, however, does not mean that the mainline Reformation churches did not have their own version of eschatological anxiety, one peculiar to a "grace alone" style of faith and attended by its own kind of competition. The Reformation of 16th-century Zürich and Geneva are likely sites for evidence of Protestant versions, as is the theological and cultural evidence Max Weber enlists in his classic work, The Protestant Ethic and the Spirit of Capitalism, trans. Talcott Parsons, foreword R. H. Tawney (New York: Scribner, 1958).

${ }^{87}$ Martin Luther, "Smalcald Articles" II.2, in The Book of Concord: The Confessions of the Evangelical Lutheran Church, trans. Theodore G. Tappert (Philadelphia: Fortress, 1959) 295. 
but to say that purgatory is simply a dreadful blasphemy against Christ?"88 If Reformation sensibilities teach the formal lesson that purgatory disappears where strong grace prevails, then perhaps we have some direction for understanding the remarkable loss of belief in purgatory since Vatican II.

As I begin to assess my second historical site for the disappearance of belief in purgatory, it is important to note that the doctrine has not disappeared entirely from contemporary Catholic culture. A tradition is always a constellation of beliefs and practices being made and remade in every passing moment. Its variety and diversity are as characteristic as the unity that believers claim for it. Within this diversity, some Catholics still believe in purgatory ardently enough to participate in all the practices associated with engaged belief in the "third place." And yet, purgatory has largely disappeared from Catholic belief and practice in the past half century, a phenomenon that begs for theological explanation. ${ }^{89}$ My introductory re-

88 John Calvin, Institutes of the Christian Religion, vol. 1 of 2, Library of Christian Classics 20, trans. Ford Lewis, ed. John T. McNeill Battles (Philadelphia: Westminster, 1977) 676 (3.5.6).

${ }^{89}$ Guillaume Cuchet documents an interesting rise in purgatorial devotions in France from the 19th century to World War I, after which the same practices wane considerably. The title of his book portrays the waning as the "twilight" of purgatory, which may be appropriate as a metaphor if the virtual loss of purgatorial belief and practice after Vatican II is conceived as a far more advanced nightfall. See Guillaume Cuchet, La crépuscule du purgatoire (Paris: Armand Colin, 2005).

Yet, documenting the disappearance of belief in purgatory is difficult. Sociological and historical studies of Catholic belief and practice since the council so completely assume its disappearance that it is not considered to be an illuminating site of investigation. The Gallup Poll Index from 1935-1997 makes no mention of purgatory (Alec M. Gallup, The Gallup Poll Cumulative Index, Public Opinion 1935-1997 [Wilmington, Del.: Scholarly Resources, Inc., 1999] 82-84). No mention of purgatory appears in the following excellent studies of postconciliar American Catholicism: Chester Gillis, Roman Catholicism in America (New York: Columbia University, 1999); Dean R. Hoge, et al., Young Adult Catholics: Religion in the Culture of Choice (Notre Dame, Ind.: University of Notre Dame, 2001); James M. O'Toole, ed., Habits of Devotion: Catholic Religious Practice in Twentieth-Century America (Ithaca, N.Y.: Cornell University, 2004). A personal story here might illustrate the experience of late middle-age Catholics who can still remember the power of purgatory in the preconciliar Church. In the year 2000 , my parish church in Trumbull, Connecticut, was designated one of several churches in the diocese where one could fulfill the conditions of a plenary indulgence to celebrate the Jubilee Year. The indulgence, of course, is meaningful in Catholic belief only as a remission of purgatorial punishment. And yet, there had been no homiletical talk of purgatory in the parish for decades. An explanation of the Jubilee-Year indulgence from the pulpit made every effort to affirm its earning as a good and virtuous thing without saying what it was exactly or mentioning its connection to purgatory at all. The assumption on the part of the homilist, I believe, was that younger members of the congregation would not know what purgatory was and that older members had long left it behind. 
marks noted that one reason for the disappearance of belief in purgatory might lie in the way that theological and pastoral reception of Vatican II highlighted the power of God's grace, and to a degree that undermined the detailed accounting of personal virtue and sin in the Tridentine merit system. I conclude by reflecting on this observation in light of my lengthy argument.

Even though conservative interpreters of Vatican II stress the unchanged continuity of its teaching with previous tradition, it is difficult to explain the extensive developments in Catholic belief and practice after the council as much to do about the same or, as conservatives are more inclined to hold, a series of misinterpretations of what the council really taught. Lumen gentium's teachings on the universal call to holiness and the common priesthood of all the faithful challenged believers to reimagine the meaning of the traditional notion of the hierarchy of discipleship in a way that accentuated the baptismal vocation of all believers. ${ }^{90}$ This ecclesiology, complemented by the same document's teaching on salvation outside the church and the church's embrace of the modern world in Gaudium et spes, encouraged believers to envision God's grace as efficacious beyond the means of the institutional church, a view supported by the influence of Rahner's theology on and after the council. The postconciliar emphasis on the availability of God's grace had a host of effects on Catholic belief and practice. It depeccativized the world. It dulled the pointed sense of God's judgment that believers felt upon their lives. It calmed the eschatological anxiety that had filled Catholic lives throughout the earlier tradition. It subverted the advantage that the ascetical vocation had found in the hierarchy of discipleship. And, finally, it caused the virtual disappearance of belief in purgatory as the tradition's late-developing and creative way of negotiating a sinful world, God's judgment, eschatological anxiety, and the burden of the ascetical vocation in the hierarchy of discipleship. ${ }^{91}$

As interesting as I find Richard Fenn's thesis that belief in purgatory has not disappeared but has become quotidian in secularized American life, I think that he has stretched the purgatorial metaphor to the breaking point. See Richard K. Fenn, The Persistence of Purgatory (New York: Cambridge University, 1995). My judgment that belief in purgatory has disappeared in the life of the church is a sociological one. I have no qualms about believing in the reality of the "third place."

90 The Dogmatic Constitution on the Church (Lumen gentium) nos. 9-17, in Vatican Council II: The Conciliar and Post Conciliar Documents, ed. Austin Flannery, O.P. (Northport, N.Y.: Costello, 1987) 359-69.

${ }^{91}$ A possible third historical site to test the eclipse of purgatory by grace is the long-held suspicion of belief in purgatory in Eastern Christianity. Here, though, it would be correct to speak of the absence of the doctrine of purgatory rather than of its disappearance. Perhaps the Eastern doctrine of uncreated grace and the 
The loss of belief in purgatory, then, was the loss of competitive religion, a loss cheered by some in the Catholic Church, lamented by others, and unconsciously lived out by so many more. Where the loss of competitive religion has entailed the believer's oblivion to meaningful guilt and a sense of judgment in the face of personal and systemic sin, there something of value has vanished from the tradition and is in desperate need of recovery. But the loss of competitive religion can also be understood as an authentic development in the tradition, a loss that brings the possible gain of a novel style of Catholic faith that we could describe as "noncompetitive." Although a number of sociological rubrics have been proposed to name the many ways of being Catholic since the council, I have not encountered the rubric "noncompetitive," which I offer not as a sociological but as a theological description that cuts across a number of Catholic behaviors that might be distinguished from the competitive religiosity of earlier Catholic belief and practice. For help in elucidating this Catholic style of faith, I enlist the important work of Kathryn Tanner.

As Tanner has argued, a noncompetitive understanding of Christian life is one deeply attuned to the graciousness of God as the giver of the gift that grace is. Since God's gifts are truly gifts and not entries into a system of barter and exchange, they cannot be returned through reciprocal action on the part of the graced. By their very nature, God's gifts dash any possibility of conditional reciprocity precisely because the persons who receive them are themselves created gifts:

God's gifts efface themselves in their giving because God's gift-giving, unlike any gift-giving among creatures with which we are familiar, is total, productive without remainder of its recipients. Because we are these gifts, we are not aware of having received them, as we would be in any ordinary case of gifts transferred from someone else's hands to us. Recognition of these gifts is itself, then, a gift from God. ${ }^{92}$

And if even an appreciative faith is a divine gift, then no conditional return to God is expected or even possible. For Tanner, God's unconditional giving communicates the divine life itself, shared as acts of complete self-giving without return among the persons of the Trinity. God's utter graciousness is simply who God is, as much as it is what God does.

image of salvation as divinization are avenues to pursue in explaining the Eastern suspicion of the belief. For a historical account of the theological differences between East and West on purgatory, see Gilbert Dagron, "La perception d'une différence: Les débuts de la "Querelle du Purgatoire," Actes du XVe Congrès International d'Études Byzantines: Athènes, Septembre 1976 (1980) 84-92.

${ }_{92}$ Kathryn Tanner, Jesus, Humanity, and the Trinity: A Brief Systematic Theology (Minneapolis: Fortress, 2001) 85. 
Understanding God's being and acting in this way means that "God's gift-giving is non-competitive." God's giving to one does not come at another's expense. "What is given," Tanner explains, "remains the possession of the one giving." 93 Grace is not a commodity that can be transferred to and then possessed by the recipient since the graced person, in the act of creation, is a divine gift too, and not some personal site for the exchange of value with God or other competing persons. God's giving does not work in that way. And even though so much giving and receiving in the world does, Tanner insists that a proper theological regard for the human person would recognize the Christian obligation to imitate the manner of God's noncompetitive gift-giving, which sets the standard for true relations in all of creation. "If our lives together imitate God's giving to us," Tanner argues, "we should not need to hold what we are or have as our exclusive possessions, or claim with respect to them exclusive rights of use, against others." 94 When owning becomes a function of giving, as it does in the act of creation, possession and rights of use relinquish any sense of propriety and become the common currency of all. And this means that

our lives as individuals should be constituted and enhanced in their perfections as we share our lives with others in community, identifying ourselves thereby as persons in community with others and not simply persons for ourselves. We perfect one another in community as our operations to perfect our own gifts and talents enter into and supplement the operations of others in a combined venture for goods otherwise impossible. ${ }^{95}$

Such "relations of non-exclusive possession and identification only make sense ...," Tanner insists, "where giving to others and having oneself are not in competition with one another."96

Tanner's reflections clearly lead in the direction of a social ethic, which, while very important, is not my principal concern here. ${ }^{97}$ Nevertheless, her thoughts on grace are a suggestive resource for explaining the present Catholic moment. If a noncompetitive style of Catholic faith has appeared in the wake of Vatican II, then Tanner's theology seems to suggest that it derives from a strong emphasis on the power of grace and an appreciation on the part of believers that the efficacy of grace devalues religious competition. Without competition among believers for a favorable divine judgment, all the dynamics of the hierarchy of discipleship dissolve away, and with them some of the typical forms of Catholic belief and practice that have flourished throughout Catholic history. For some in the Catholic Church, this change in belief and practice constitutes a fateful loss. Yet,

\footnotetext{
93 Ibid. 90, 91.

95 Ibid. 93.

94 Ibid. 91.

96 Ibid.

97 Tanner develops the specifically economic implications of this theological motif in Kathryn Tanner, Economy of Grace (Minneapolis: Fortress, 2005).
} 
with this noncompetitive style of faith comes a host of possible gains to the tradition. The loss of competitive religion may have resulted in a paucity of vocations to the ascetical life, but the rise of a noncompetitive style of faith has witnessed a new appreciation for the baptismal responsibilities of all believers. The loss of competitive religion may have diminished the practice of auricular confession, but the rise of a noncompetitive style of faith may have increased Catholic devotion to the Eucharist and its reception, perhaps the clearest ritualistic expression of a noncompetitive Catholic sensibility. The loss of competitive religion may have resulted in a loss of devotion to the saints and their heroic spiritual achievements, but the rise of a noncompetitive style of faith may have led to a new awareness of the social dimension of Catholic ethics in an increasingly globalized world. The loss of competitive religion may have resulted in the collapse of a Matthean style of faith, but the rise of a noncompetitive style of faith may have recovered Pauline dimensions of the Catholic tradition that have been too long overlooked.

A possible objection to this account of novel development in recent Catholic tradition is that it makes Tanner's theology of grace a template of explanation, one that requires Catholic anthropology and ecclesiology to fit the Procrustean bed of a classically Protestant theology of grace. But Tanner's stance is not classically Protestant. Its insistence on a noncompetitive understanding of grace and the Christian life seems to entail the rejection of a doctrine of double predestination, a rejection on which a Catholic theology of grace will always rightly insist. Moreover, Tanner's theology of grace does not undermine the believer's responsibility for his or her words and deeds in the face of divine judgment. As important as these words and deeds are, though, for the faithful Christian life, they do not enter into a system of exchange with God or into competition with others that would make grace a commodity instead of a gift. "God's giving is not owed to creatures," Tanner states, " but if those gifts are being given unconditionally by God to all in need, creatures are in fact owed the goods of God by those ministering such benefits, without being or having done anything in particular to deserve them. Our good works, in short, are not owed to God but they are to the world." 98 This understanding of the relationship between grace and works thoroughly respects the teaching of the Council of Trent that human initiative comes at the prompting of grace and yet our works are freely chosen and matter for our salvation, not as merit but as acts that imitate, however minimally, God's noncompetitive gift-giving. This understanding of grace and works also opens some promising avenues for an interpretation of the communion of saints in the pluralistic world in which we live.

${ }^{98}$ Tanner, Jesus, Humanity, and the Trinity 89. 
If a desire for the end of competitive religion inhabited purgatory in the passivity of the suffering souls, then perhaps that desire continues to live on even in purgatory's absence, ironically in a postconciliar style of faith that is typically blamed for purgatory's disappearance. Whether a noncompetitive style of Catholic faith can endure and thrive as the tradition to come depends on whether an authentic Catholicism is possible without an ascetical center of gravity for the pressing soteriological issues of time and judgment. It is interesting to consider that the late medieval blossoming of purgatory coincided with the rise of Western individualism. Perhaps the competitive élan of the hierarchy of discipleship was energized even more by that cultural event and translated imaginatively into the extended time of purgatorial judgment for the individual believer. Catholic believers will always and rightly be concerned about their individual judgment. A noncompetitive style of faith, though, may be more inclined to broaden that concern to include all peoples and all of history. In this theological perspective, salvation is as much a corporate as it is an individual event, and the time of history is as important for negotiating the salvation of the human community as the supernatural time of purgatory has been for negotiating God's judgment on individual believers in light of the ascetical standard. A noncompetitive Catholic faith, then, is rife with eschatological implications for the ancient traditional belief in the Last Judgment and the communal proportions of salvation.

No doubt, a noncompetitive eschatology will be attended by its own brand of anxiety, as will any account of the Christian life that is serious about judgment. But it will be an anxiety shared by believers who trouble about their undeserved reception of God's innumerable gifts. This will not be an anxiety stirred by the competitive envy of the least who aspire to be the most, but rather an anxiety disturbed by the sinful possibility of competition for God's favor in a community of solidarity rightly appreciative of God's graceful subversion of competitive judgment. 